Life Sciences Contributions 126
Royal Ontario Museum

Upper Cambrian to

Lower Ordovician Conodont

Biostratigraphy and Biofacies,

Rabbitkettle Formation,

District of Mackenzie

Ed Landing

Rolf Ludvigsen

Peter $\mathrm{H}$. von Bitter

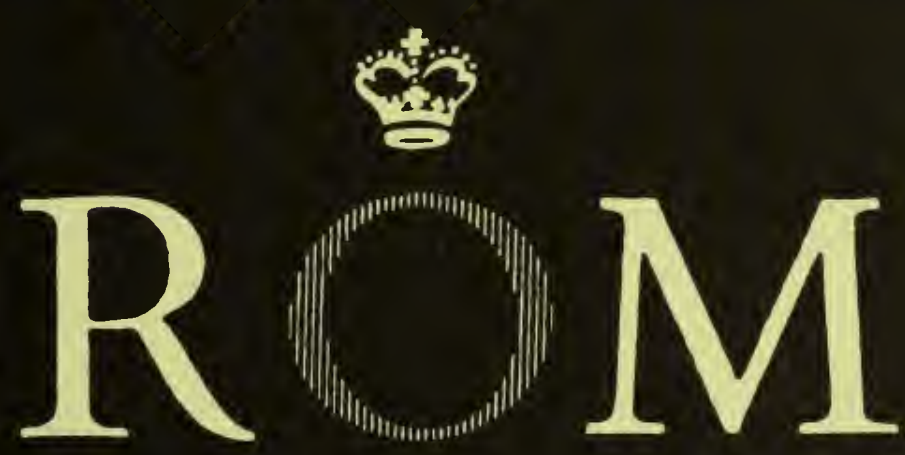




\section{ROYAL ONTARIO MUSEUM LIFE SCIENCES PUBLICATIONS INSTRUCTIONS TO AUTHORS}

Authors are to prepare their manuscripts carefully according to the following instructions. Failure to do so will result in the manuscript's being returned to the author for revision. All manuscripts are considered on the understanding that if accepted they will not be offered for publication elsewhere.

1. GENERAL Papers for publication are accepted from ROM staff members, Research Associates, or from researchers reporting on work done with ROM collections. In exceptional cases, monographic works on the flora and/or fauna of Ontario will be considered for publication by authors not affiliated with the ROM. Authors are expected to write clearly and concisely, and to omit all material not essential for an understanding of the main theme of the paper.

2. FORMAT Manuscripts are to be typed double-spaced (including captions, synonomies, literature cited, and tables) on $11^{\prime \prime} \times 8 \frac{1}{2}$ " paper with a $1 \frac{112}{2}$ " margin on all sides. Three xerox copies are to be submitted to the Chairman of the Editorial Board, and the original retained by the author(s). A separate sheet is to be submitted giving author(s) names, affiliation, title of publication, series in which it is to appear, number of typed pages, number of tables, and number of figures. Manuscripts should normally be organized in the following order: Table of Contents, Abstract, Introduction, Materials and Methods, Results, Discussion, Conclusions, Summary (if paper is long), Acknowledgements, Literature Cited, and Appendices. Authors are encouraged to include foreign language translations of the Summary where appropriate. Headings of sections are to be left-justified to the text margin. The first line of the first paragraph in each new section should not be indented. Text-figures are referred to as "Fig. 1". Literature cited in the text is in the form "Jones (1972)" or "(Jones, 1972)" or "(Smith, 1960:71-79, fig. 17)".

3. STANDARD SOURCES The primary source for decisions on format and style is A Guide for Contributors and Editors of ROM Life Sciences Publications, available from the Chairman of the Editorial Board. Otherwise, consult CBE (AIBS) Style Manual (3rd Edition). Other standard sources are as follows: for English spelling (Concise Oxford Dictionary), for Canadian place names and coordinates (Gazetteer of Canada), and for spelling of geographic names (Times [London] Atlas).

4. ABSTRACT All papers are preceded by a short and factual abstract, about 3 per cent as long as the text, but not longer than 400 words. The abstract is to be followed by four to six keywords enclosed in brackets.

5. TAXONOMY The name of a taxon is given in full in headings, where it appears for the first time, or when the name begins a paragraph. Use authority and date if appropriate, with first mention of each taxon and not thereafter. Taxonomic papers follow the layout in Life Sciences Contribution 99, particularly the synonomies.

6. LITERATURE CITED References in the text cite author and date and are enclosed in parentheses (Smith, 1978). Complete references are listed in alphabetical order by author at the end of the paper. When there are two or more citations for an author, the works are listed chronologically. Names of journals are not abbreviated. Consult Life Sciences Contributions beginning with 117 for correct bibliographic form.

7. TABLES All tables are numbered consecutively in arabic numerals in numerical order of their first mention in the text. Mark the appropriate text location of each table with a marginal notation. Each table is typed on a separate sheet. Avoid footnotes etc., to tables by building them into the title.

8. FIGURES All figures are numbered consecutively in arabic numerals. Component photographs or drawings are labelled sequentially in upper case letters. Mark the appropriate text location of each figure with a marginal notation. The intended reduction for figures is ideally one and a half to two times. All labelling on figures is in blue pencil and not inked or letraset. Halftones must be photographic prints of high contrast on glossy paper. Authors are to submit 10 " $\times 8$ " copies with the MS and retain originals until they are requested. Figure captions are to appear grouped together on a separate page at the end of the MS. 
ED LANDING

ROLF LUDVIGSEN

PETER H. von BITTER
Upper Cambrian to

Lower Ordovician Conodont Biostratigraphy and Biofacies, Rabbitkettle Formation,

District of Mackenzie

\section{RO̊̉M}




\section{ROYAL ONTARIO MUSEUM PUBLICATIONS IN LIFE SCIENCES}

The Royal Ontario Museum publishes three series in the Life Sciences:

LIFE SCIENCES CONTRIBUTIONS, a numbered series of original scientific publications including monographic works.

LIFE SCIENCES OCCASIONAL PAPERS, a numbered series of original scientific publications, primarily short and usually of taxonomic significance.

LIFE SCIENCES MISCELLANEOUS PUBLICATIONS, an unnumbered series of publications of varied subject matter and format.

All manuscripts considered for publication are subject to the scrutiny and editorial policies of the Life Sciences Editorial Board, and to review by persons outside the Museum staff who are authorities in the particular field involved.

\section{LIFE SCIENCES EDITORIAL BOARD}

Senior Editor: J. H. MCANDREWS

Editor: R. D. JAMES

Editor: C. MCGOWAN

ED LANDING was a post-doctoral fellow of the Department of Earth Sciences, University of Waterloo, Waterloo, Ontario, and is with the United States Geological Survey, Paleontology and Stratigraphy Branch, Mail Stop 919, Denver Federal Center, Denver, Colorado 80225, USA.

ROLF LudvigSEn is Associate Professor in the Department of Geology, University of Toronto, and Research Associate, Department of Invertebrate Palaeontology, Royal Ontario Museum.

PETER H. von BITTER is Associate Curator-in-charge in the Department of Invertebrate Palaeontology, Royal Ontario Museum, and Associate Professor, Department of Geology, University of Toronto.

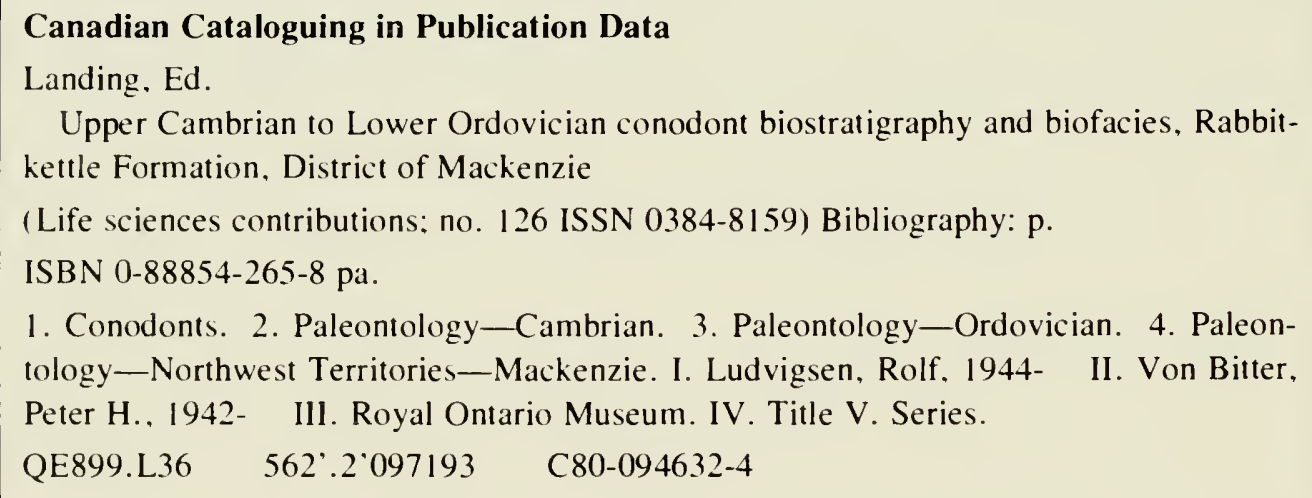

Publication date: 10 October 1980

ISBN 0-88854-265-8

ISSN 0384-8159

(C) The Royal Ontario Museum, 1980

100 Queen`s Park, Toronto, Canada M5S 2C6

PRINTED AND BOUND IN CANADA BY DEYELL 


\title{
Upper Cambrian to \\ Lower Ordovician Conodont \\ Biostratigraphy and Biofacies, \\ Rabbitkettle Formation, \\ District of Mackenzie
}

\begin{abstract}
Conodonts have been recovered from two sections through the Cambrian-Ordovician boundary beds of the upper Rabbitkettle Formation, near the headwaters of the Broken Skull River, western Mackenzie Mountains. The two sections are separated by a thrust fault. The sequence of trilobite faunas from the low-energy outer shelf facies of the Rabbitkettle is equivalent to the Saukiella junia through Symphysurina brevispicata subzones from the inner carbonate platform in Oklahoma and Texas. Significant differences in trilobite faunas between the Mackenzie Mountains and United States sequences represent contrasting biofacies developments. Similarly, the sparse and low diversity conodont faunas of the Rabbitkettle resemble coeval Appalachian continental slope and outer shelf faunas rather than those reported from the inner carbonate platform in Texas and Utah. The Proconodontus and Cordylodus oklahomensis (new name) zones can be recognized in the Rabbitkettle but cannot be divided into the subzones established in Utah. These data suggest that lithofacies associations and biofacies developments in conodont distribution may prohibit detailed conodontbased correlations of Cambrian-Ordovician boundary beds.
\end{abstract}

\section{Introduction}

Uppermost Cambrian and lowest Ordovician conodonts are known from sections in the western United States (Miller, 1969, 1970, 1975, 1977, 1978; Kurtz, 1976), Alberta (Derby et al., 1972), Iran (Müller, 1973), and Australia (Druce and Jones, 1971). The similarities of conodont faunal sequences in these widely separated areas have been interpreted to reflect a lack of or weak development of conodont biofacies or provincialism in Cambrian-Ordovician boundary beds (Barnes et al., 1973). Land- 
ing et al. (1978) suggested that conodont faunas bridge the biofacies differences shown by trilobites. Consequently, conodonts have received considerable discussion in intercontinental correlation of Cambrian-Ordovician boundary beds (Jones et al., 1971; Miller, 1977, 1978; Landing et al., 1978).

Available lithologic information indicates that the North American, Iranian, and Australian conodont successions listed above were derived from intertidal or very shallow sublittoral, inner carbonate platform sequences. Similarities of the faunal successions may reflect the appearance of comparable conodont assemblages ("communities") in similar but geographically separated environments.

Based on studies of continental slope deposits in the northern Appalachians, Landing $(1978,1979)$ proposed that major conodont biofacies differences existed during the uppermost Cambrian and lowest Ordovician. Faunas from inner carbonate platform sequences appear to differ from those in sequences deposited in environments with unrestricted access to the open ocean.

The upper Rabbitkettle Formation in the western Mackenzie Mountains (Fig. 1) has lithologic and faunal features representative of an open shelf facies. The trilobite

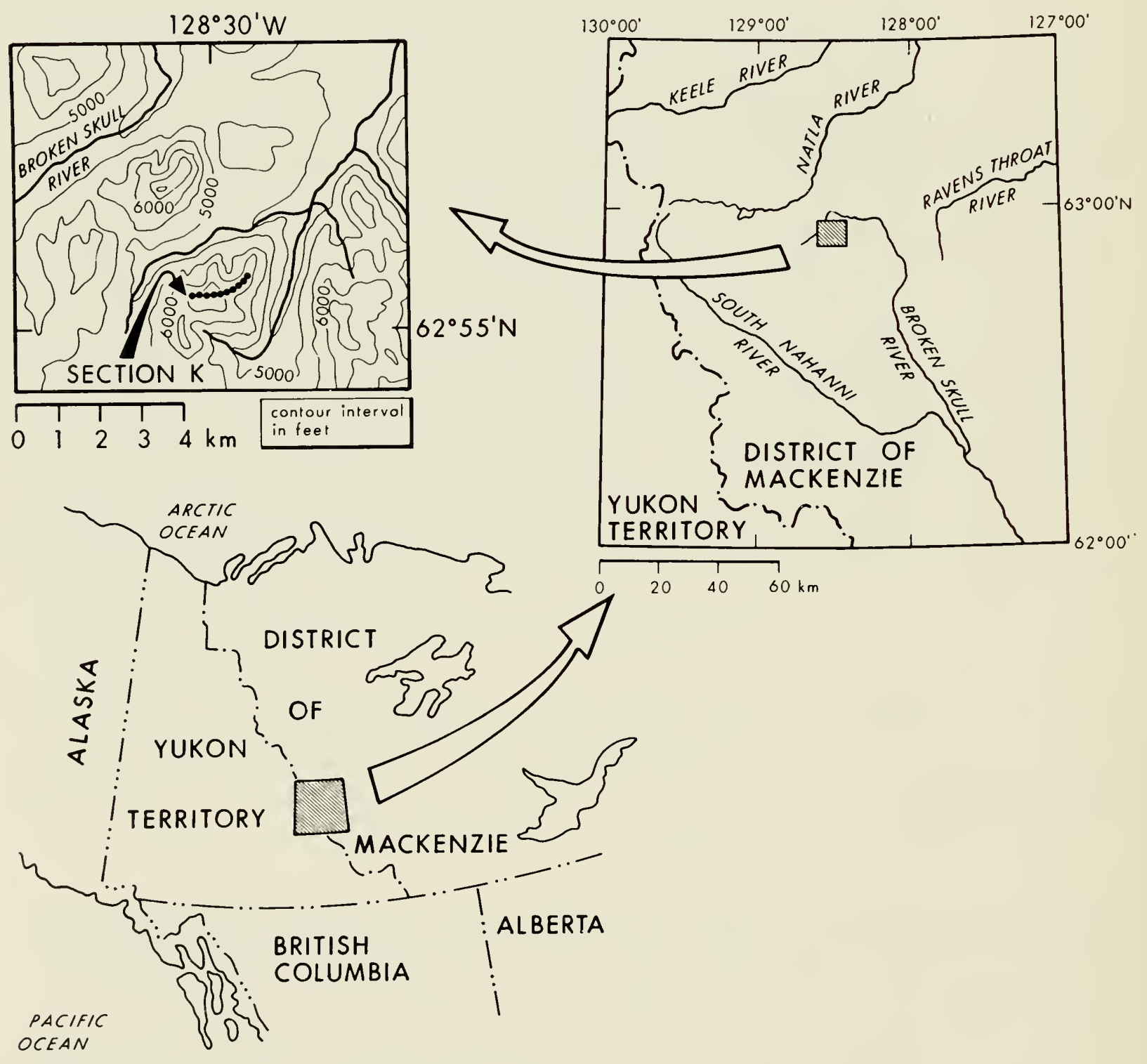

Fig. 1 Locality maps showing Section K. 
sequence from this interval, briefly summarized in this report, can be correlated with those from the uppermost Cambrian to lowest Ordovician successions of Texas (Winston and Nicholls, 1967; Longacre, 1970) and Oklahoma (Stitt, 1971, 1977) although significant differences in faunal composition are present. These differences are attributed to the more open marine biofacies represented by the Rabbitkettle trilobites. Conodonts were examined to determine whether the sequences and composition of open shelf faunas from the Rabbitkettle have closer affinity to Miller's (1969, 1970, 1975, 1978) diverse carbonate platform conodont faunas or to Landing's (1978, 1979) coeval low diversity conodont faunas with restricted biostratigraphic utility from slope sequences.

This report contributes towards a biofacies evaluation of Cambrian-Ordovician boundary bed conodonts and illustrates the probable limitations on a highly resolved conodont-based correlation of this interval between strongly contrasting lithofacies.

\section{Geologic Setting and Stratigraphy}

Three formations of Late Cambrian and Early Ordovician age are exposed on the Mackenzie Platform, a stable tectonic element which received dominantly shallowwater sediments from the Helikian to the Late Devonian (Gabrielse, 1967): the Franklin Mountain Formation in the Mackenzie Valley (Norford and Macqueen, 1975), the Broken Skull Formation in the eastern and central Mackenzie Mountains (Gabrielse et al., 1973; Ludvigsen, 1975), and the Rabbitkettle Formation in the western Mackenzie Mountains and the Selwyn Mountains (Gabrielse et al., 1973).

These formations are poorly dated. Scattered fossil collections suggest that each spans the interval of, at least, Franconian to Canadian (Norford and Macqueen, 1975; Gabrielse et al., 1973; Ludvigsen, 1975; Tipnis et al., 1979).

The Rabbitkettle Formation comprises a thick sequence of grey weathering and banded silty limestones and calcareous siltstones near the border between the District of Mackenzie and Yukon Territory. Complete stratigraphic sections have not been located, but Gabrielse et al. (1973) suggested a minimum thickness of $1200 \mathrm{~m}$ for the Rabbitkettle in the Selwyn Mountains. Towards the east, the Rabbitkettle is replaced by silty and sandy, locally cross-bedded and pisolitic limestones and dolostones of the Broken Skull Formation which are, in turn, replaced by stromatolitic dolostones of the Franklin Mountain Formation further to the east.

Detailed biostratigraphic work on the upper Rabbitkettle Formation dates from 1972 when Ludvigsen measured a $750 \mathrm{~m}$ section of Upper Cambrian and Ordovician rocks near the headwaters of the Broken Skull River (Fig. 1). This section, designated Section K (Fig. 2), includes the upper Rabbitkettle Formation and the lower Road River Formation. A prominent black dolostone member overlying the Rabbitkettle was initially assigned to the lower Sunblood Formation and a significant hiatus was presumed to separate these units (Ludvigsen, 1975: fig. 7). However, Tipnis et al. (1979) demonstrated that Early Arenigian conodonts occur above the black dolostone member and that the hiatus, if indeed present, must be minor. This dolostone unit is herein considered to be a basal member of the Road River Formation. 


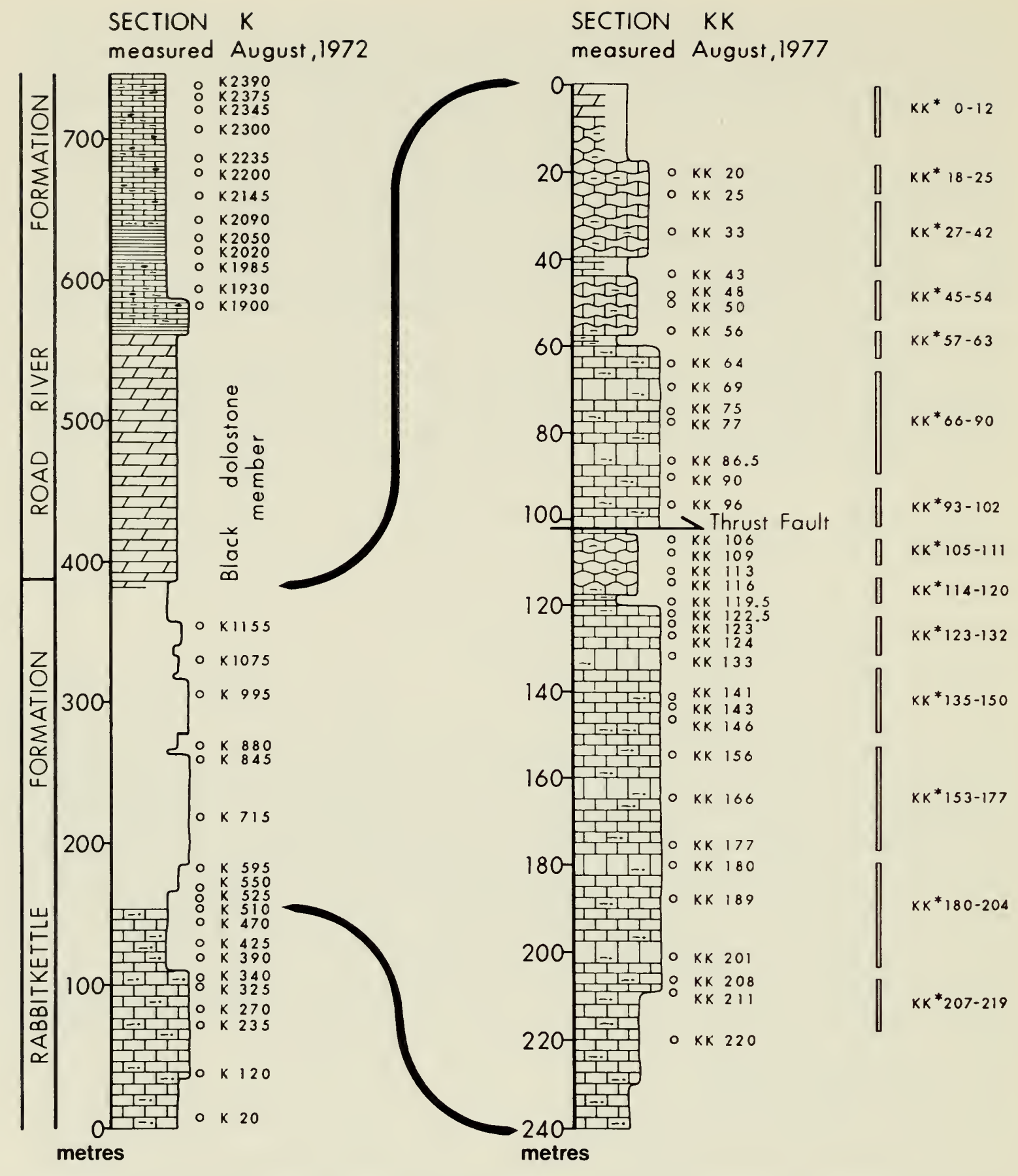

Fig. 2 Diagram of Section K showing the samples ( $\mathrm{K}$ prefix) that yielded the conodonts discussed by Tipnis et al. (1979). When Section K was measured, it was considered to represent a continuous and structurally uncomplicated stratigraphic section. Detailed sampling of the upper $240 \mathrm{~m}$ of the Rabbitkettle Formation (Section KK) provided evidence of a thrust fault located $102 \mathrm{~m}$ below the top of the formation. Thus, the interval 44-102 $\mathrm{m}$ of the hanging wall corresponds to the interval $102-160 \mathrm{~m}$ of the foot wall. The position of samples dissolved in the search for conodonts is indicated (KK prefix). Also shown are the intervals represented by composite samples $\left(\mathrm{KK}^{*}\right.$ prefix).

The recovery of silicified trilobites at a number of levels below the black dolostone in Section $\mathrm{K}$ prompted a reinvestigation of this part of the section, and the upper $240 \mathrm{~m}$ of the Rabbitkettle was sampled in detail by Ludvigsen in 1977. This new section was designated Section KK (Fig. 2). Thirty-five bulk limestone samples, ranging in weight from 2 to more than $20 \mathrm{~kg}$, were collected through the section. One and 


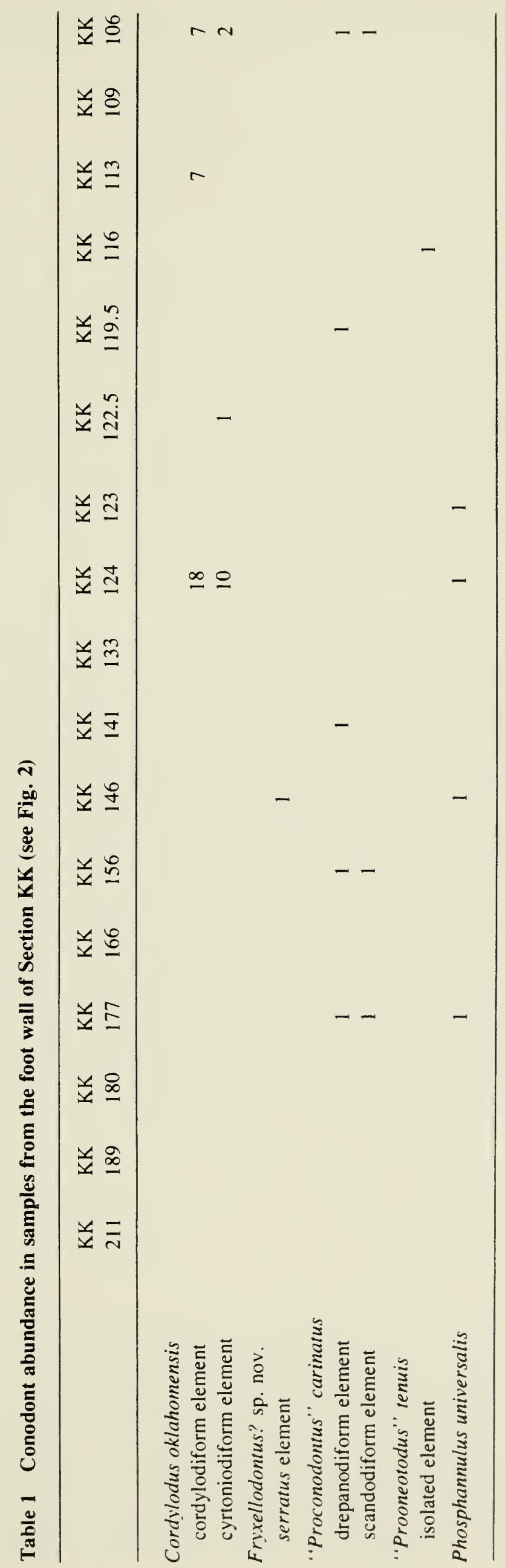

5 


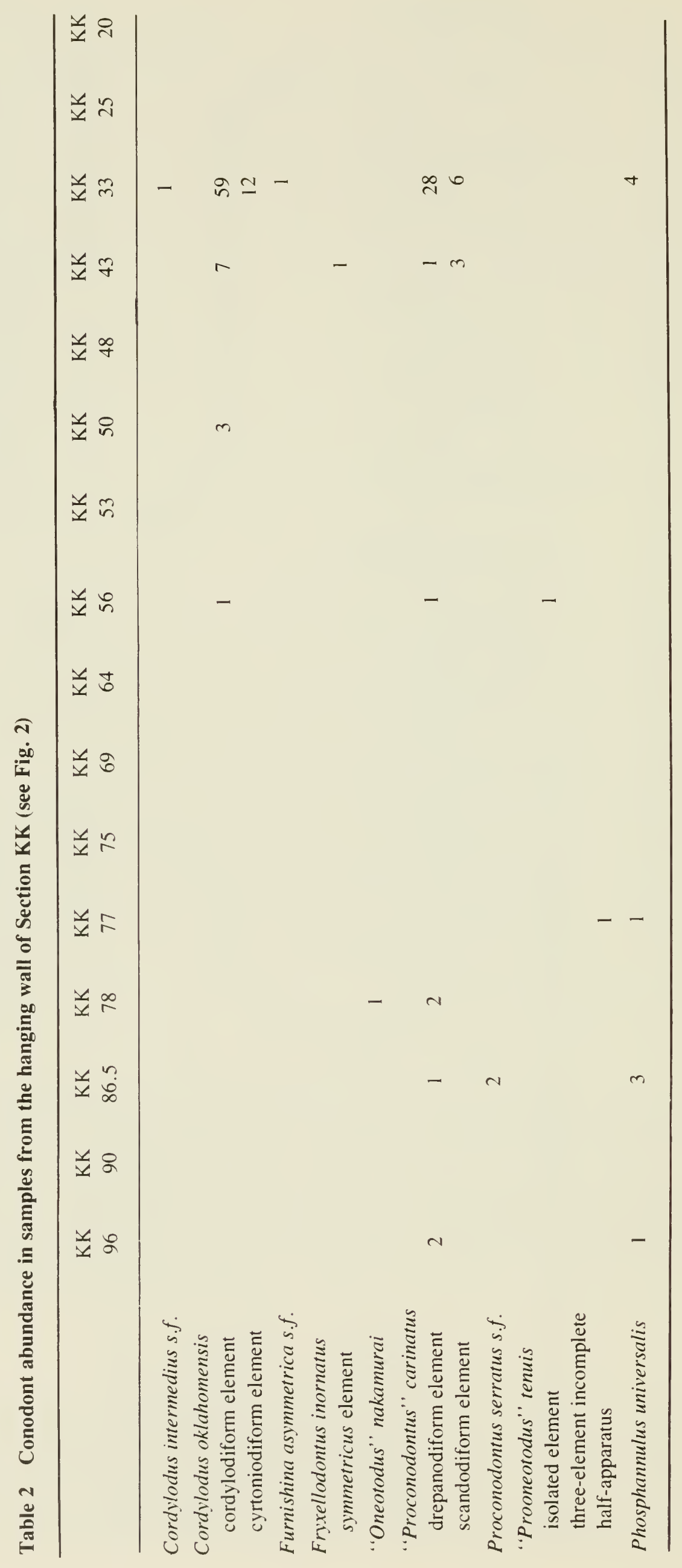


Table 3 Conodont abundance in productive composite samples from the foot and hanging walls of Section KK (see Fig. 2)

\begin{tabular}{|c|c|c|c|c|}
\hline & $\begin{array}{c}\mathrm{KK}^{*} \\
135-150\end{array}$ & $\begin{array}{c}\mathrm{KK}^{*} \\
45-54\end{array}$ & $\begin{array}{c}\mathrm{KK}^{*} \\
27-42\end{array}$ & $\begin{array}{l}\mathrm{KK} * \\
0-12\end{array}$ \\
\hline \multicolumn{5}{|l|}{ Cordylodus oklahomensis } \\
\hline cyrtoniodiform element & & 1 & 3 & \\
\hline "Oneotodus" nakamurai & 1 & & & \\
\hline $\begin{array}{l}\text { "Proconodontus" carinatus } \\
\text { drepanodiform element } \\
\text { scandodiform element }\end{array}$ & & & & 1 \\
\hline Proconodontus serratus s.f. & 1 & & & \\
\hline Protoconodont sp. indet. s.f. & 2 & & & \\
\hline Phosphannulus universalis & 1 & & & \\
\hline
\end{tabular}

one-half to $2 \mathrm{~kg}$ of each sample were dissolved in acetic acid to recover conodonts; the remainder was dissolved in hydrochloric acid in the search for silicified trilobites. The samples are identified by a letter/number combination (e.g., KK 50) indicating the distance in metres below top of the Rabbitkettle Formation. In addition, a suite of hand samples, identified in the form of $\mathrm{KK}^{*} 0-12$ to indicate the stratigraphic interval represented by these composite samples, was processed to recover conodonts.

Examination of the sequence of silicified trilobites in Section KK led to the recognition that a $58 \mathrm{~m}$ interval in the upper Rabbitkettle Formation is repeated by a thrust fault which is located $102 \mathrm{~m}$ below the top of the formation (Fig. 2). The interval KK 44 to KK 102 of the hanging wall corresponds to the interval KK 102 to KK 160 of the foot wall of the thrust. The repeated interval includes the Cambrian-Ordovician boundary. The resulting composite Section KK (Fig. 3) shows the true stratigraphic thickness of the interval from KK 220 to the top of the Rabbitkettle to be about $160 \mathrm{~m}$. In this paper, levels within the upper Rabbitkettle are cited as distances in metres below the top of the formation in the composite section.

\section{Previous Investigations}

Tipnis et al. (1979) outlined a conodont succession for Section K (Fig. 2). Biostratigraphically nondiagnostic Upper Cambrian conodonts were recovered from samples K 270 and K 390 ( $249 \mathrm{~m}$ and $213 \mathrm{~m}$ below the top of the Rabbitkettle Formation). Proconodontus muelleri Miller s.f. (= sensu formo) in K 525 (172 m below top of Rabbitkettle) represents some portion of Miller's $(1975,1977)$ Proconodontus Zone and suggests a possible early or middle Trempealeauan age. Similarly, their report of "Oneotodus" nakamurai Nogami, "O. cf. O. datsonensis" Druce and Jones and "O. simplex" (Furnish) (here regarded as "O." nakamurai), Oistodus cf. cambricus 


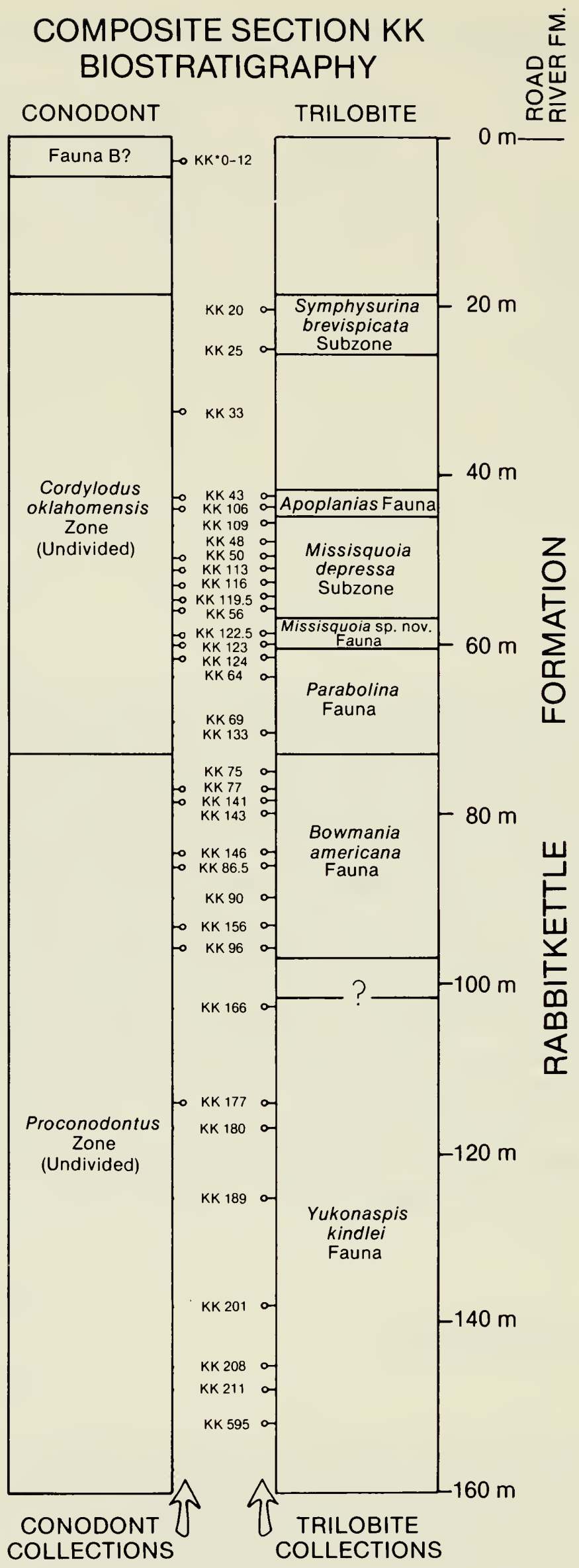

Fig. 3 Composite Section KK showing restored stratigraphic position of samples from the foot and hanging walls of the thrust fault. Productive conodont and trilobite samples are indicated, as are the stratal limits for the conodont and trilobite biostratigraphic units that are discussed in the text. 
Miller s.f. and Proconodontus spp. s.f. in K 715 (112 m below top of Rabbitkettle) represents Miller's $(1975,1978)$ Proconodontus notchpeakensis or Oistodus minutus subzones of the Proconodontus Zone. This fauna indicates an equivalency with the upper Saukiella junia or S. serotina subzones of the Saukia Zone in Utah (Miller, 1978). Cordylodus spp. s.f. in association with Missisquoia Zone trilobites from K 880 (57 m below top of Rabbitkettle) represents the lowest Ordovician portion of Miller's (1975) Cordylodus proavus Zone.

An illustrated drepanodiform element, Drepanodus cf. D. simplex Furnish s.f., with "Oneotodus" spp. from K 995 and unfigured platform elements from . K 11:50 ( $60 \mathrm{~m}$ and $25 \mathrm{~m}$ below top of Rabbitkettle) were respectively referred to Ethington and Clark's (1971) Fauna B (K 995) and the middle or upper Tremadocian (K 1150). The occurrence of North Atlantic lower Arenigian (K 1900), middle Arenigian (K 2020-K 2145), and upper Arenigian or Llanvirnian (K 2375) conodonts from the Road River Formation suggests that no significant unconformity is present above the Rabbitkettle Formation (Tipnis et al., 1979).

\section{Trilobite Sequence}

The lower 76 m of the composite section (KK 166 to KK 211 and K 510 to K 595 in the foot wall) is assigned to the Yukonaspis kindlei Fauna and is considered correlative to the Saukiella junia Subzone of Texas and Oklahoma. This correlation is based on the presence of Euptychaspis typicalis Ulrich, Triarthropsis limbata Rasetti, Heterocaryon tuberculatum Rasetti, Rhaptagnostus clarki (Kobayashi), and Calvinella cf. prethoparia Longacre as well as stratigraphic position below the superjacent biostratigraphic unit. This interval also includes species of Richardsonella (?), Eurekia, Tatonaspis, and a saukiid, as well as Yukonaspis kindlei.

The next $22 \mathrm{~m}$ in the composite section (KK 141 to KK 156 in the foot wall and KK 75 to KK 156 in the hanging wall) is assigned to the Bowmania americana Fauna. Yukonaspis, Richardsonella (?), Idiomesus, Eurekia, Heterocaryon, Liostracinoides, Bowmania americana (Walcott), and two new genera also occur in this fauna.

Overlying the Bowmania americana Fauna in the composite section is a $9 \mathrm{~m}$ interval assigned to the Parabolina Fauna (KK 124 to KK 133 in the foot wall and KK 64 in the hanging wall). This fauna includes Parabolina sp. nov., Richardsonella (?) cf. quadrispinosa Palmer, Bienvillia cf. corax (Billings), and "Leiobienvillia" leonensis Winston and Nicholls, in addition to species of Yukonaspis, Geragnostus, Idiomesus, Eurekia, and Plethometopus. A single specimen of Missisquoia occurs in KK 133. This fauna is correlated with the Corbinia apopsis Subzone of Texas and Oklahoma.

A narrow stratigraphic interval above the Parabolina Fauna in the foot wall (KK 122.5 and KK 123) contains a low diversity assemblage of Missisquoia sp. nov., Parabolinella, Geragnostus, and Plethometopus. This is named the Missisquoia sp. nov. Fauna. It is not certain whether this represents an older level than the base of the Missisquoia Zone in Oklahoma.

The next $12 \mathrm{~m}$ of the composite section (KK 109 to KK 119.5 in the foot wall and 
KK 48 to KK 56 in the hanging wall) is confidently assigned to the Missisquoia depressa Subzone. This interval is very fossiliferous and contains Parabolinella sp. nov., Parabolinella hecuba (Walcott), Missisquoia depressa Stitt, Ptychopleurites brevifrons (Kobayashi), Geragnostus, Levisaspis glabrus (Shaw), and Plethometopus.

Overlying the Missisquoia depressa Subzone in the composite section is an interval (KK 106 in the foot wall and KK 43 in the hanging wall) dominated by Parabolinella, Apoplanias, and Geragnostus. This is named the Apoplanias Fauna and is tentatively correlated with the Missisquoia typicalis Subzone of Oklahoma.

The highest trilobite-bearing interval in the Rabbitkettle Formation is a narrow interval (KK 20 and KK 25 in the hanging wall) with Apoplanias, Symphysurina cf. brevispicata Hintze, and Geragnostus. These collections are correlated with the $S$. brevispicata Subzone of the Symphysurina Zone in Oklahoma.

Considerable problems are encountered in correlating the trilobite succession in the upper Rabbitkettle Formation at Section KK with coeval successions in central Texas (Winston and Nicholls, 1967; Longacre, 1970) and the Arbuckle and Wichita Mountains of Oklahoma (Stitt, 1971, 1977). Saukiid trilobites, the prime biostratigraphic indices of the Trempealeauan zonation established in Texas by Winston and Nicholls (1976) and Longacre (1970), are uncommon in the Rabbitkettle Formation. Calvinella is the only well-represented member of this family in Section KK and it only occurs in a single collection. Other important genera of the latest Cambrian zonation in Texas and Oklahoma, such as Acheliops, Bayfieldia, Rasettia, Stenopilus, Theodenisia, Briscoia, Keithiella, Bynumina, Bynumiella, and Corbinia have not been recovered from the Rabbitkettle Formation.

One of the few firm correlation tie-points between the Northwest Territories and Oklahoma (Fig. 4) is the $12 \mathrm{~m}$ thick Missisquoia depressa Subzone in the Rabbitkettle which undoubtedly is correlative with the $6 \mathrm{~m}$ thick $M$. depressa Subzone in the Signal Mountain Limestone in Oklahoma (Stitt, 1977). The substantial difference in generic composition within this subzone suggests the influence of environmental factors. The $M$. depressa Subzone in Oklahoma is strongly dominated by Plethopeltis (about $85 \%$ of 260 specimens). This genus does not occur in Section KK where the subzone is dominated by Parabolinella (about $65 \%$ of 760 specimens). Geragnostus is also much more abundant in the $M$. depressa Subzone in Section KK than in Oklahoma.

Each of the 14 trilobite collections from the base of the Missisquoia sp. nov. Fauna to the Symphysurina Zone at Section KK is dominated by olenid and agnostid trilobites. In addition, two olenids and one agnostid occur in the Parabolina Fauna. Thus, the upper part of Section KK is numerically dominated by trilobites characteristic of slope and outer shelf facies in the Lower Palaeozoic (Lochman-Balk and Wilson, 1958; Fortey, 1975; Taylor, 1977; Ludvigsen, 1979a). The evidence for the lower part of Section KK is less clear, but it is not inconsistent with a similar outer shelf position (Taylor, 1977:table 3). Section KK, therefore, records a sequence of trilobite faunas which, in comparison with coeval inner shelf sequences in Texas and Oklahoma, appears to represent an unrestricted open marine sequence deposited in an outer shelf setting. 


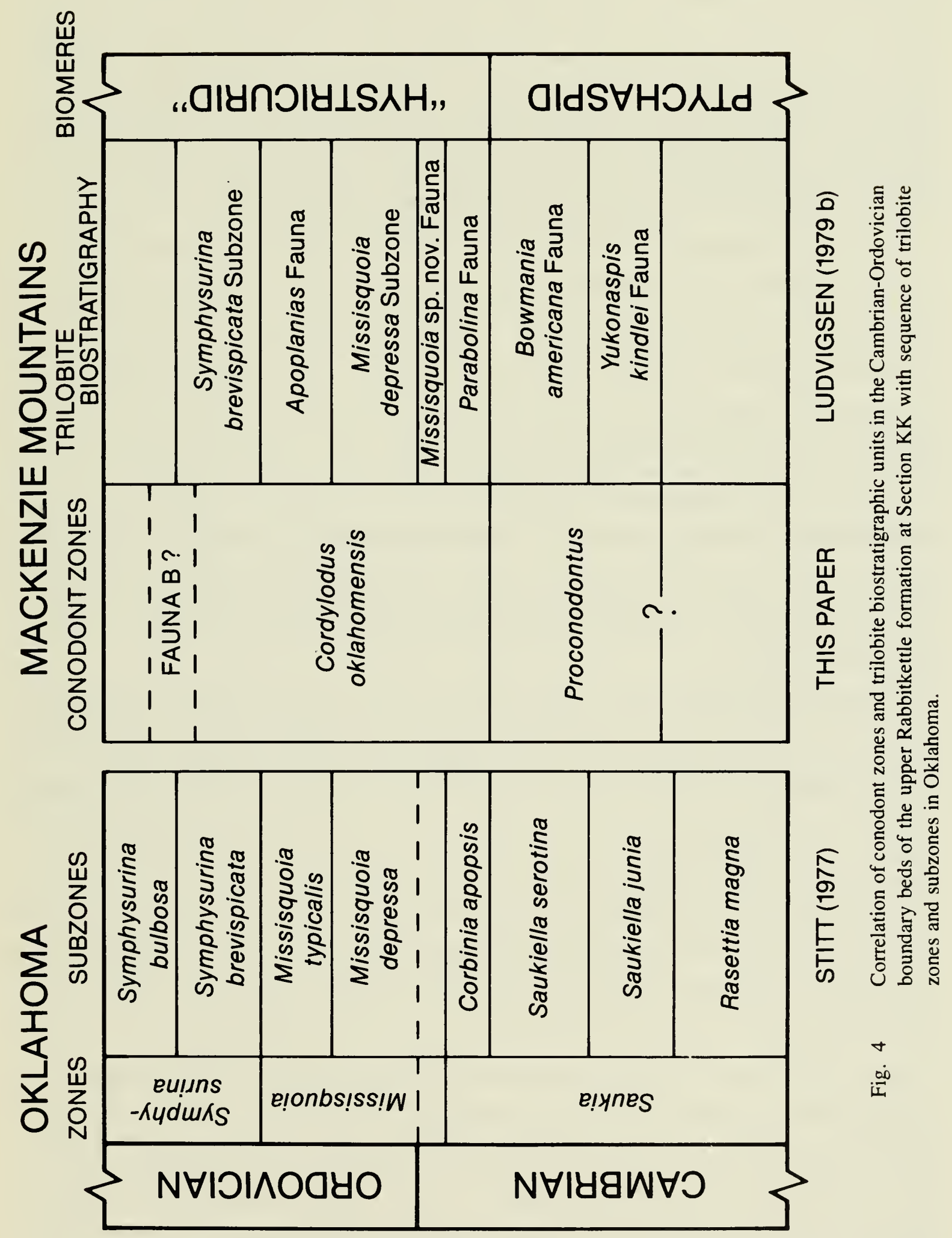




\section{Depositional Setting}

Dark grey, thinly bedded, more-or-less silty lime mudstone and fossiliferous lime wackestone that regularly alternate with finely laminated, thinner calcareous siltstones dominate the section. Thin oolitic and granule intraclastic lime wackestones and packstones appear in the Yukonaspis kindlei Fauna and the Bowmania americana Fauna. Bedding surfaces are typically planar with sedimentary boundinage appearing with the Parabolina Fauna and through higher strata. Bioturbation and light grey lime wackestones and mudstones are present only in the Bowmania americana Fauna interval. Trilobite remains observed on bedding surfaces and in etched residues are typically disarticulated but are neither abraded nor severely broken.

The regular alternations of fine-grained silty, dark limestones and thinner calcareous siltstones with occasional well-sorted and winnowed allochem limestones suggest episodic deposition generally below effective wave base. The absence of features such as penecontemporaneously contorted and folded beds, slumps, mass movement deposits occupying channels, and carbonate flyschoid beds with erosional bases precludes deposition on or at the foot of a steep submarine slope. Such features appear in coeval fine-grained clastics of the Road River Formation in the Selwyn Basin to the northwest of Section K (Cecile, 1978).

Similarly, a restricted marine, very shallow or intertidal, inner shelf depositional environment is not indicated because of the absence of fenestral fabric, flat pebbles, channels and scour and fill structures, early dolomitized lime mudstone, prominent bioturbation, algalaminates and stromatolites, wave or tidally produced sedimentary structures, evaporites, and light coloration (Roehl, 1967; Shinn, 1968; Wilson, 1970, 1974; Cook, 1972).

The upper Rabbitkettle Formation of Section KK contains few lithologic features which can be assigned to a unique depositional environment. However, it is probable that these beds were deposited under low energy open shelf or very low angle muddy slope conditions. It is questionable whether Wilson's (1969) association of the type of sedimentary boudinage present within the Lower Ordovician of Section KK with shallow subtidal shelf deposition below effective wave base is appropriate. The presence of intercalated oolitic, intraclastic, and fossiliferous (trilobite and "pelmatozoan') grainstones and packstones low in the sequence suggests that lime mud and silt deposition was punctuated by the transport of allochthonous carbonate debris by nonturbid bottom traction currents or nonturbid sand sheet flows. The source of this debris quite likely lay to the east in the area of platform deposition of the Broken Skull Formation.

A two-fold division is apparent in the rocks of Section KK: 1) a lower sequence of planar bedded, medium to light grey and silty lime mudstones, wackestones, and grainstones, which locally are bioturbed, and 2) an upper sequence of wavy bedded, dark grey and silty lime mudstones which lack bioturbation. This lithologic division also coincides with a pronounced fanual division. The lower sequence (Yukonaspis kindlei Fauna and Bowmania americana Fauna) contains typical Saukia Zone trilobites and the upper sequence (Parabolina Fauna to Symphysurina brevispicata Subzone) is dominated by olenids, agnostids, and trilobites of probable extra-North American origin. The base of the Parabolina Fauna thus coincides with a significant environmental change and this level was interpreted by Ludvigsen (1979b) as a biomere boundary. 


\section{Conodont Sequence}

\section{General}

Ten multi-element and form species are represented among the 202 specimens recovered from 23 of 45 samples. Conodont elements have a thermal colour alteration index of 4.5 to 5 (Epstein et al., 1977) and slightly corroded surfaces. The sparse, low diversity conodont faunas from Section KK can be compared with Miller's $(1975,1977,1978)$ conodont zonation of the western USA.

\section{Proconodontus Zone}

Conodonts from the upper Yukonaspis kindlei Fauna and Bowmania americana Fauna intervals of Section KK include multi-element "Proconodontus" carinatus Miller (= Proconodontus carinatus s.f. and P. notchpeakensis Miller $s . f$.), P. serratus Miller s.f., "Oneotodus" nakamurai Nogami, "Prooneotodus" tenuis (Müller), and Furnishina asymmetrica Müller.

Miller (1978) has equated the upper Saukiella junia Subzone and lowest S. serotina Subzone with the Proconodontus notchpeakensis Subzone of the Proconodontus Zone. The first appearance of Oistodus minutus Miller s.f. in the lower S. serotina Subzone and its persistence to the top of that trilobite subzone defines the Oistodus minutus Subzone of the upper Proconodontus Zone.

Oistodus minutus s.f. was not recovered in this study. Consequently, the faunally similar Proconodontus notchpeakensis and $O$. minutus subzones cannot be differentiated in Section KK.

"Oneotodus" nakamurai appears in the Bowmania americana Fauna in Section KK. The species has its lowest occurrence in the Corbinia apopsis Subzone in the western United States where it regularly appears along with the first Cordylodus form species (Miller, 1975, 1977, 1978; Kurtz, 1976). However, “O.' nakamurai occurs in rocks older than those bearing Cordylodus in the People's Republic of China (Nogami, 1967), Alberta (Derby et al., 1972), Appalachian North America (Landing, 1977, 1979), Korea (Lee, 1975), and Australia (Druce and Jones, 1971).

A single element representing Fryxellodontus? sp. nov. from the Bowmania americana Fauna is a possible Upper Cambrian representative of the genus. Fryxellodontus lineatus Miller and $F$. inornatus Miller first appear at the base of the Lower Ordovician Missisquoia typicalis Subzone in the western United States (Miller, 1977, 1978).

Tipnis et al. (1979) report an anomalous occurrence of Clavohamulus cf. C. bulbousus (Miller) from K 390 (213 m below the top of the Rabbitkettle). The species is known from the upper Missisquoia typicalis Subzone and lower Symphysurina Zone in the western USA (Miller, 1978). The occurrence of the species below the lowest studied trilobites in Section KK (Yukonaspis kindlei Fauna) suggests that the Clavohamulus lineage originated considerably before the Lower Ordovician. 
The disappearance of several conodont species and the appearance of Cordylodus proavus Müller s.f., C. oklahomensis Müller s.f., "Oneotodus" nakamurai, and Hirsutodontus at the base of the Corbinia apopsis Subzone define the base of Miller's (1975, 1977, 1978) Cordylodus proavus Zone. Miller (1975, 1977, 1978) has divided the latest Cambrian through lowest Ordovician Cordylodus proavus Zone (= Corbinia apopsis Subzone-lower Symphysurina Zone) into five subzones.

Cordylodus proavus s.f. is part of multi-element $C$. oklahomensis (see Systematic Palaeontology) and the designation "Cordylodus oklahomensis Zone" is here substituted for "C. proavus Zone".

Cordylodus oklahomensis Zone faunas from Section KK are sparse and of low diversity. The eponymous species first appears in uppermost Cambrian strata equivalent to the Corbinia apopsis Subzone although the species was not recovered in this study from the base of the Parabolina Fauna. However, the Proconodontus and C. oklahomensis Zone faunas are not as strongly differentiated as they are in Texas, Utah, and Wyoming (Miller, 1975, 1977, 1978; Kurtz, 1976). As noted above, "Oneotodus" nakamurai first appears in the Proconodontus Zone in the Rabbitkettle. In addition, Tipnis et al. (1979) note the co-occurrence of Proconodontus muelleri Miller s.f. with Cordylodus proavus s.f. and Missisquoia in $\mathrm{K} 880(57 \mathrm{~m}$ below top of Rabbitkettle Formation). The persistence of $P$. muelleri into the Lower Ordovician contrasts with the species' disappearance just below the Corbinia apopsis Subzone in the western USA (Miller, 1975, 1977, 1978; Kurtz, 1976). Proconodontus Zone species also persist into the local range zone of Cordylodus oklahomensis in Vermont (Landing, 1979).

Miller's subzonal sequence of the Cordylodus oklahomensis Zone is based on the range zones of species of Hirsutodontus, Clavohamulus, and Fryxellodontus. The absence of these forms precludes division of the zone in Section KK. A single element of Fryxellodontus inornatus from KK 43 supports the tentative correlation of the Apoplanias Fauna with the Missisquoia typicalis Subzone. Miller (1978) documents the occurrence of $F$. inornatus through the Fryxellodontus inornatus and lower Clavohamulus subzones (middle Cordylodus oklahomensis Zone) and equates these with the Missisquoia typicalis Subzone.

The youngest conodont collection $\left(\mathrm{KK}^{*} 0-12\right)$ consists of one element of "Proconodontus" carinatus. This composite sample was collected above the highest trilobite collection (KK 20) and could represent either the upper Cordylodus oklahomensis Zone or Ethington and Clark's (1971) Fauna B. This uncertain correlation is due to the absence of associated Cordylodus form species. Fauna B is recognized by the appearance of advanced form species of Cordylodus, including Cordylodus lindstromi Druce and Jones, 1971, and C. intermedius Furnish, 1938 (Miller, 1975). However, 1) the recovery of $C$. intermedius from the Cordylodus oklahomensis Zone (Miller, 1978; Landing, 1979; this report), 2) the probability that " $C$. lindstromi" is an ontogenetic variant with supernumerary basal tips that appears in all Cordylodus elements (Landing, 1979), and 3) the persistence of upper Cordylodus oklahomensis Zone species into Fauna B (Miller, 1970; Landing, 1979) make the differentiation of Fauna B unclear at present. 


\section{Conodont Biofacies}

Although conodonts are sparsely represented in samples from Section KK, the faunal sequence has closer similarities with continental slope sequences from the Appalachians (Landing, 1979) than with inner carbonate platform successions in the western USA (Miller, 1969, 1970, 1975, 1977, 1978; Kurtz, 1976). These differences are most obvious in the generic composition of the euconodont components (Bengtson, 1976) of Cordylodus oklahomensis Zone faunas.

Multi-element "Proconodontus" carinatus and Cordylodus oklahomensis and mono-elemental "Oneotodus" nakamurai are dominant species both in continental slope and inner carbonate platform sequences. These three species are represented by 83 per cent of the elements from Miller's (1978) Lava Dam Five section in the upper Notch Peak Limestone and lower House Limestone, western Utah. Species of Clavohamulus, Fryxellodontus, and Hirsutodontus, which are used for the subzonation of the Cordylodus oklahomensis Zone (Miller, 1975), are represented by 7 per cent of the elements at the Lava Dam Five section. Although elements of Clavohamulus, Fryxellodontus, and Hirsutodontus are relatively minor components of Cordylodus oklahomensis Zone faunas in shallow-water sequences, these components are absent or very sparingly represented in continental slope deposits in the Appalachians. Landing (1979) recovered only one element of Fryxellodontus lineatus from the Highgate and Gorge formations, northwestern Vermont. Similarly, representatives of the three genera have not been encountered in Cordylodus oklahomensis Zone faunas from the Green Point Group, western Newfoundland (E. Landing, unpublished data). Similar Cordylodus oklahomensis Zone faunas are present in the lower Grove Formation, at Lime Kiln, central Maryland (E. Landing, unpublished data) where the transition from the upper Frederick Limestone to the lower Grove Formation represents a progradation of shallow shelf carbonates over fine-grained carbonates (Reinhardt, 1974). The lower Grove Formation at Lime Kiln consists of festoon bedded, oolite bar deposits. This shelf margin sequence has yielded low diversity conodont faunas comprised of Cordylodus, "Proconodontus", and "Oneotodus".

The reasons for the absence or near absence of Clavohamulus, Fryxellodontus, and Hirsutodontus from the outermost shelf or slope environments listed above and from the Rabbitkettle Formation are unknown. Water depth and energy of the environment do not seem to be common factors which would limit their distribution. It is possible that representatives of the three genera were adapted to variable and/or elevated salinities and temperatures of the restricted marine conditions of the inner shelf and were environmentally stenotopic. Cordylodus species and the ancestral "Proconodontus" carinatus and "Oneotodus" nakamurai are geographically widespread in terms of lithofacies associations and were presumably eurytopic.

Biofacies developments in euconodont distributions in Proconodontus Zone faunas are obscure at present. Landing (1979) did not encounter Oistodus minutus Miller s.f. in upper Proconodontus Zone faunas in slope deposits in northwestern Vermont. The form was recovered in turbiditic limestones in the Taconic allochthon (Landing, 1977, 1979) although it is absent in the uppermost Cambrian in the Green Point Group, western Newfoundland (E. Landing, unpublished data). Similarly, deep shelf lithotopes of the uppermost Frederick Limestone, central Maryland, have not yielded the species. It is possible that $O$. minutus may be found to be more regularly associated with restricted, marine inner shelf deposits. 


\section{Discussion}

Reinvestigation of the lithologic and faunal sequences of Section KK demonstrates the stratigraphic repetition of the section by a thrust fault located $102 \mathrm{~m}$ below the top of the Rabbitkettle Formation. Tipnis et al. (1979) recovered lowest Ordovician conodonts and trilobites at K 880 (Fig. 2). Conodonts from their sample K 995 higher in the section do not represent Ethington and Clark's (1971) Fauna B and are referable to the preuppermost Cambrian Proconodontus Zone (Saukiella serotina Subzone equivalent). Similarly, the report of middle or upper Tremadocian "platform elements" from K 1150 (30.4 m below top of Rabbitkettle) (Tipnis et al. 1979) cannot be evaluated because the specimens were not illustrated. However, conodonts recovered in this study from KK 33 and $\mathrm{KK}^{*} 0-12$ seem to represent the upper Cordylodus oklahomensis Zone or, possibly, Fauna B, and are of Lower Tremadocian aspect.

As discussed above, the Rabbitkettle Formation at Section KK has no lithologic features indicating shallow, inner carbonate platform deposition. The deep, outer shelf or low angle slope depositional environment suggested above is supported by the composition of uppermost Cambrian and lowest Ordovician trilobite faunas.

The absence of Clavohamulus and Hirsutodontus and poor representation of Fryxellodontus in Cordylodus oklahomensis Zone faunas from the Rabbitkettle Formation at Section KK are considered to be related to unrestricted marine conditions of deposition and have parallels in Appalachian outermost shelf and continental slope faunas. Although it is less clear, the absence of Oistodus minutus s.f. in the upper Proconodontus Zone may also be related to the palaeogeographic setting of Section KK.

Miller's $(1975,1977,1978)$ conodont-based subzonation of the uppermost Cambrian through lowest Ordovician (Saukiella junia Subzone through lower Symphysurina Zone) provides a biostratigraphic resolution comparable to that provided by trilobite faunas. However, the absence of key conodont species in Cambrian-Ordovician boundary beds in outer shelf and slope deposits results in recognition only of the Proconodontus and Cordylodus oklahomensis zones and not faunas referable to conodont subzones. This biofacies control of conodonts has probable implications for conodont-based correlations of Cambrian-Ordovician (Olenidian-Tremadocian series) boundary beds of the classic Acado-Baltic biofacies of the Cambrian and Ordovician systems. The deposition of the carbonate-poor Acado-Baltic sequences of this age in palaeogeographic settings that had unrestricted access to the open ocean (Ross, 1975) suggests that conodont species required for subzonation of the Proconodontus and Cordylodus oklahomensis zones may not be encountered here with enough regularity for precise correlations. Landing et al. (1978) recovered only Proconodontus carinatus s.f. and Cordylodus proavus s.f. in the uppermost Cambrian in the AcadoBaltic sequence on Navy Island, New Brunswick, and did not encounter the Hirsutodontus species which appear in the lowest Cordylodus oklahomensis Zone in the western USA (see also Miller, 1977, 1978). 


\section{Systematic Palaeontology}

\section{Remarks}

Conodont taxa are listed alphabetically. A suprageneric classification is not applied although the informal designations "protoconodont", "paraconodont", and "euconodont" (Bengtson, 1976) are used to summarize the growth modes of conodont elements. Conodont form species are designated in sensu formo (s.f.) when the composition of the apparatus is unknown. The presumed hyolithelminthoid Phosphannulus is listed at the end of the section.

\section{Repository}

Royal Ontario Museum, Toronto (ROM). Figured specimens are stored under ROM numbers 38361 to 38375 . Topotype collections from the upper Rabbitkettle Formation are reposited under ROM numbers 38401 to 38444 .

\section{Phylum uncertain \\ Class uncertain \\ Order Conodontophorida Eichenberg, 1930}

Genus Cordylodus Pander, 1856

\section{Type Species}

Cordylodus angulatus Pander, 1856, s.f. from the Early Ordovician glauconitic sandstones of Estonia.

\section{Emended Diagnosis}

Euconodonts represented by a bi-elemental apparatus consisting of a numerically predominant cordylodiform element and a subordinate cyrtoniodiform element. Cusp and denticles are albid and the elements lack any surface microsculpture.

\section{Discussion}

Previous reconstructions of the Cordylodus apparatus (Bergström and Sweet, 1966; Sweet and Bergström, 1972; Barnes and Poplawski, 1973; Nowlan, 1976) are not followed in this report and J. F. Miller's (pers. comm. to E. L., 1977) reconstruction is followed. The Cordylodus apparatus is bi-elemental and consists of an element with rounded denticles and cusp and a second element with laterally flattened, basally confluent denticles and cusp. The former, termed the "rounded element" by Miller, is here designated the "cordylodiform element" because this plan is shown by the type form species. The second element, Miller's "flattened element", is termed the "cyrtoniodiform element" because its plan is similar enough to Cyrtoniodus Stauffer $s . f$. that some authors (Miller, 1970; Ethington and Clark, 1971) have referred " flattened elements" to that form genus. 
Cordylodiform elements are generally more abundant in collections than cyrtoniodiform elements. The former are more variable in a large collection than associated cyrtoniodiform elements and show a more-or-less distinctive symmetry transition series (see also Ethington and Clark, 1971 : 68, pl. 1, figs. 15, 16, 20). Cordylodiform elements designated in the literature as 1) Cordylodus proavus Müller s.f., 2) C. intermedius Furnish s.f., and 3) " $C$. lindstromi" Druce and Jones s.f. are externally identical. They are separable, respectively, by 1) a convex anterior margin of the basal cavity, 2) a straight to concave anterior margin of the basal cavity, and 3) convex to concave anterior profile of the basal cavity and presence of secondary basal tips. The associated cyrtoniodiform elements are 1) $C$. oklahomensis Müller, s.f., 2) an unnamed element often misidentified as $C$. oklahomensis or $C$. prion Lindström s.f. and 3) an element included by Druce and Jones (1971) in the definition of " $C$. lindstromi' s.f. These cyrtoniodiform elements are distinguished by developments in the anterior profile of the basal cavity which parallel those in the cordylodiform element.

" "Cordylodus lindstromi" elements are not considered to represent a biologic species. Druce and Jones (1971) illustrated a cyrtoniodiform holotype (pl. 1, figs. 9a, b, text-fig. 23h) and paratype cordylodiform (pl. 1, figs. 7a-8b, pl. 2, figs. 8a-c) elements with secondary basal tips. One paratype (pl. 2, figs. $8 \mathrm{a}-\mathrm{c}$ ) has a convex anterior margin of the basal cavity and is comparable to $C$. proavus s.f. with exception of a second basal tip. A second paratype (pl. 1, figs. 7a, b) has the straight anterior margin of the basal cavity which is present in early elements of $C$. intermedius. Druce and Jones's (1971) holotype of " $C$. lindstromi" is otherwise comparable to the cyrtoniodiform element of Cordylodus intermedius. Miller (1970) illustrated in nomen nudum forms designated Cordylodus insertus sp. nov. s.f. and $C$. sp. aff. insertus sp. nov. s.f. These elements are closely similar to $C$. proavus s.f. and $C$. oklahomensis s.f., respectively, but have an additional basal tip.

Accessory apices of the basal cavity are regarded in this report as not of significance in the classification of Cordylodus and are developmental variants. The anterior profile of the basal cavity is considered to have primary significance in the classification of Cordylodus elements. Although Miller $(1975,1977)$ has used the first appearance of "Cordylodus lindstromi" in defining Ethington and Clark's Fauna B, he has illustrated a $C$. oklahomensis s.f. element from the underlying Cordylodus oklahomensis Zone with secondary apices of the basal cavity (Miller, 1969: pl. 65, fig. 53). Nowlan (1976) recovered ' $C$. lindstromi" from sequences older than Fauna B.

Advanced Cordylodus intermedius gave rise to multi-element $C$. angulatus Pander and $C$. rotundatus Pander of Fauna $C$. The latter apparatuses have apparently indistinguishable cyrtoniodiform elements referable to $C$. prion Lindström s.f. (J. F. Miller, pers. comm. to E. L., 1977). The "phrygian cap" anterior profile of the basal cavity of $C$. angulatus s.f. and $C$. rotundatus s.f. is a more exaggerated condition than that seen in the concave profile of $C$. intermedius $s . f$.

Cordylodus is a characteristic latest Cambrian and Tremadocian genus in the North American, Australasian, Siberian, and Acado-Baltic faunal provinces (Müller, 1959, 1973; Miller, 1969; Druce and Jones, 1971; Abaimova and Markov, 1977; Landing, et al., 1978). Van Wamel (1974) reported the genus in the lower Arenigian of Sweden. Dzik (1976) renamed a Llanvirnian and Llandeilian apparatus containing cordylodiform and ramiform elements Spinodus spinatus (Hadding). Cordylodus horridus 
s.f. of Barnes and Poplawski (1973) from the uppermost Arenigian (Landing, 1976) seems to be part of an undescribed apparatus (R. L. Ethington, pers. comm. to E. L. 1978).

The ancestor of the earliest appearing Cordylodus species, Cordylodus oklahomensis, appears to have been a middle Trempealeauan species consisting of Proconodontus carinatus Miller $s$.f. and $P$. notchpeakensis Miller $s . f$.

\section{Cordylodus intermedius Furnish, 1938, s.f.}

Figs. 5E, 6A, B

Cordylodus intermedius Furnish, 1938:338, pl. 42, fig. 31, text-fig. 2C.

Cordylodus insertus Miller, 1970:88, 89 (nomen nudum) (pars, pl. 1, figs. 37, 38).

Cordylodus cf. C. angulatus-Druce and Jones, 1971:67, text-fig. 23c.

Cordylodus caseyi Druce and Jones, 1971:67, 68, pl. 2, figs. 9a-12c, text-figs. 23d, e.

Cordylodus intermedius-Druce and Jones, 1971:68, pl. 3, figs. 1a-3b, text-figs. 23f, g.

Cordylodus proavus-Druce and Jones, 1971:70, 71, (pars, pl. 1, figs. 1a, b, 3, 5a-6, text-figs. 23p, q, (non C. proavus Müller, 1959, s.f.).

Cordylodus cf. C. proavus -Druce and Jones, 1971:71, (pars, pl. 1, figs. 10a-11b, non C. proavus Müller, 1959, s.f.).

Cordylodus caseyi-Jones, 1971:46, pl. 2, figs. 1a-c.

Cordylodus intermedius-Jones, 1971:46, pl. 2, figs. 2a-3c.

Cordylodus lindstromi-Jones, 1971:47, pl. 2, figs. 4a-c.

Cordylodus intermedius-Müller, 1973:30, pl. 10, figs. 1a-3, text-figs. 2c, 4a, b.

Cordylodus lenzi Müller, 1973:31, pl. 10, figs. 5-9, text-figs. 2f, 5a, b.

Cordylodus angulatus-Viira, 1974:63, (pars, pl. 1, fig. 8, text-figs. 4a, b, non C. angulatus Pander, 1856, s.f.).

Cordylodus angulatus-van Wamel, 1974:58, 59, (pars, pl. 1, figs. 6, 7, non C. angulatus Pander, 1856, s.f.).

Cordylodus intermedius-Repetski, 1975:44, 45, pl. 1, figs. 11, 12.

Cordylodus intermedius - Nowlan, 1976:149, 150, pl. 2, figs. 1, 2.

?Cordylodus cf. C. intermedius-Tipnis et al., 1979:31, pl. 1, fig. 7.

Cordylodus intermedius-Landing, 1979:62-64, 133-135, 200-201, pl. II-3, fig. 3, pl. III-1, fig. 8, pl. IV-2, fig. 6 (pars, citations listed are only those of $C$. intermedius $s . f$.).

\section{Occurrence and Hypotype}

One element (ROM 38373) from KK 33. The associated conodont fauna represents the upper Cordylodus oklahomensis Zone.

\section{Remarks}

The shape of the basal cavity of Cordylodus intermedius s.f. is intermediate between those of $C$. proavus s.f. and $C$. angulatus s.f. as noted by Druce and Jones (1971) and 

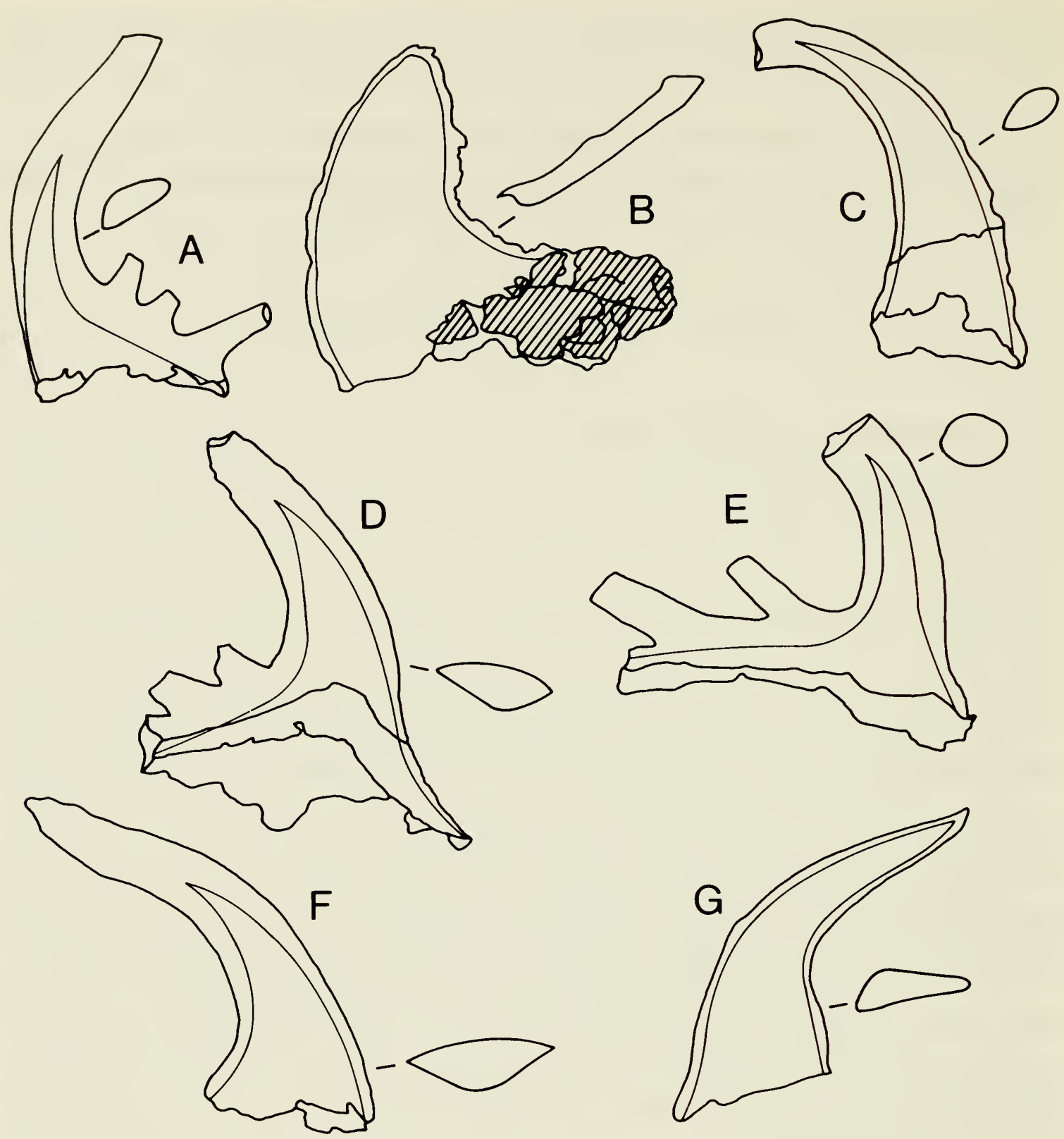

Fig. 5A, D Cordylodus oklahomensis Müller, cordylodiform, ROM 38372, $\times 70$, and cyrtoniodiform, ROM $38367, \times 75$, elements, respectively.

B Fryxellodontus? sp. nov. Lateral view of serrrated elements with attached pyrite crystals (diagonal ruling), ROM $38366, \times 60$.

C, F "Proconodontus" carinatus Miller, drepanodiform, ROM 38365, $\times 60$, and scandodiform, ROM $38362, \times 150$, element, respectively.

E Cordylodus intermedius Furnish $s . f .$, ROM $38373, \times 140$.

G Protoconodont sp. indet. s.f., ROM $38375, \times 55$.

Müller (1973). The element (Fig. 6A) has rounded denticles and cusp and has a straight anterior profile of the basal cavity which differs from the convex profile present in cordylodiform elements of $C$. oklahomensis. The surface of the element has undergone slight dissolution and blocky crystallites are exposed on the surface (Fig. 6B). 


\section{Cordylodus oklahomensis Müller, 1959}

Figs. 5A, D, 6C-E

\section{Cordylodiform Element}

Cordylodus proavus Müller, 1959:448, 449, pl. 15, figs. 11, 12, 18, text-fig. 3B. Cordylodus proavus-Miller, 1969:424-426, pl. 65, figs. 37-45, text-fig. 3D.

Cordylodus insertus Miller, 1970:88, 89 (nomen nudum), (pars, pl. 1, fig. 37, textfig. 11B).

Cordylodus proavus-Miller, 1970:89, text-fig. 11D.

Cordylodus lindstromi Druce and Jones, 1971:68, 69, pl. 2, figs. 8a-c (pars).

Cordylodus proavus-Druce and Jones, 1971:70, 71 (pars, pl. 1, figs. 2a, b, 4a, b, text-fig. 23r).

Cordylodus cf. C. proavus-Druce and Jones, 1971:71, (pars, pl. 1, figs. 12a, b, text-fig. 23s).

Cordylodus proavus-Ethington and Clark, 1971:71, pl. 1, fig. 19.

Cordylodus proavus - Jones, 1971:48, pl. 2, figs. 9a-c.

Cordylodus proavus-Miller and Melby, 1971:120, pl. 1, figs. 18, 19.

Cordylodus proavus-Müller, 1973:35, pl. 9, figs. 1-4, 9, text-figs. 2a, 9a, b.

Cordylodus angulatus - van Wamel, 1974:58, 59 (pars, pl. 1, fig. 5, non C. angulatus Pander, 1856, s.f.).

Cordylodus proavus-Abaimova, $1975: 109,110$, pl. 10, fig. 16, text-fig. 8 $(27,28)$.

Cordylodus proavus-Nowlan, 1974:15, pl. 1, figs. 9, 10, 14-16.

Cordylodus proavus - Abaimova and Markov, 1977:91, pl. 14, fig. 1.

Cordylodus proavus - Landing et al., 1978:76, text-fig. 2F.

Cordylodus proavus-Fåhraeus and Nowlan, 1978:453, pl. 1, figs. 8, 9.

Cordylodus proavus-Tipnis et al., 1979:31, pl. 1, figs. 8, 9.

?Cordylodus cf. C. proavus-Tipnis et al., 1979:31, pl. 1, fig. 10.

Cordylodus proavus-Landing, 1979:21, 22, pl. I-1, figs. 10, 13.

Cordylodus oklahomensis-Landing, 1979:64, 65, 135, 136, 202, 203, pl. II-3, fig. 1, pl. III-1, fig. 11 , pl. IV-2, fig. 8 (pars, cited figures only of $C$. proavus s.f.).

\section{Cyrtoniodiform Element}

Cordylodus oklahomensis Müller, 1959:447, 448, pl. 15, figs. 15a-16.

Cordylodus oklahomensis-Miller, 1969:423, 424, pl. 65, figs. 46-53.

Cordylodus sp. aff. C. insertus Miller, 1970:89, pl. 1, fig. 40, text-fig. 11C.

Cyrtoniodus oklahomensis-Miller, 1970:90, 91, pl. 1, figs. 35, 36, text-fig. $11 \mathrm{~F}$.

non Cordylodus oklahomensis-Druce and Jones, 1971:69, pl. 5, figs. 6a-7c, text-

fig. 23 (= cyrtoniodiform element of Cordylodus intermedius Furnish apparatus).

Cordylodus oklahomensis-Ethington and Clark, 1971:71, pl. 1, fig. 24.

Cyrtoniodus prion-Miller and Melby, 1971:120 (pars, pl. 2, fig. 17, non C. prion Lindström. 1955, s.f.).

?Cordylodus oklahomensis-Jones, 1971:47, 48, pl. 2, figs. 5a-8b.

Cordylodus oklahomensis-Müller, 1973:33, pl. 9, figs. 12-13b, text-figs. 2B, $7 \mathrm{a}, \mathrm{b}$. 

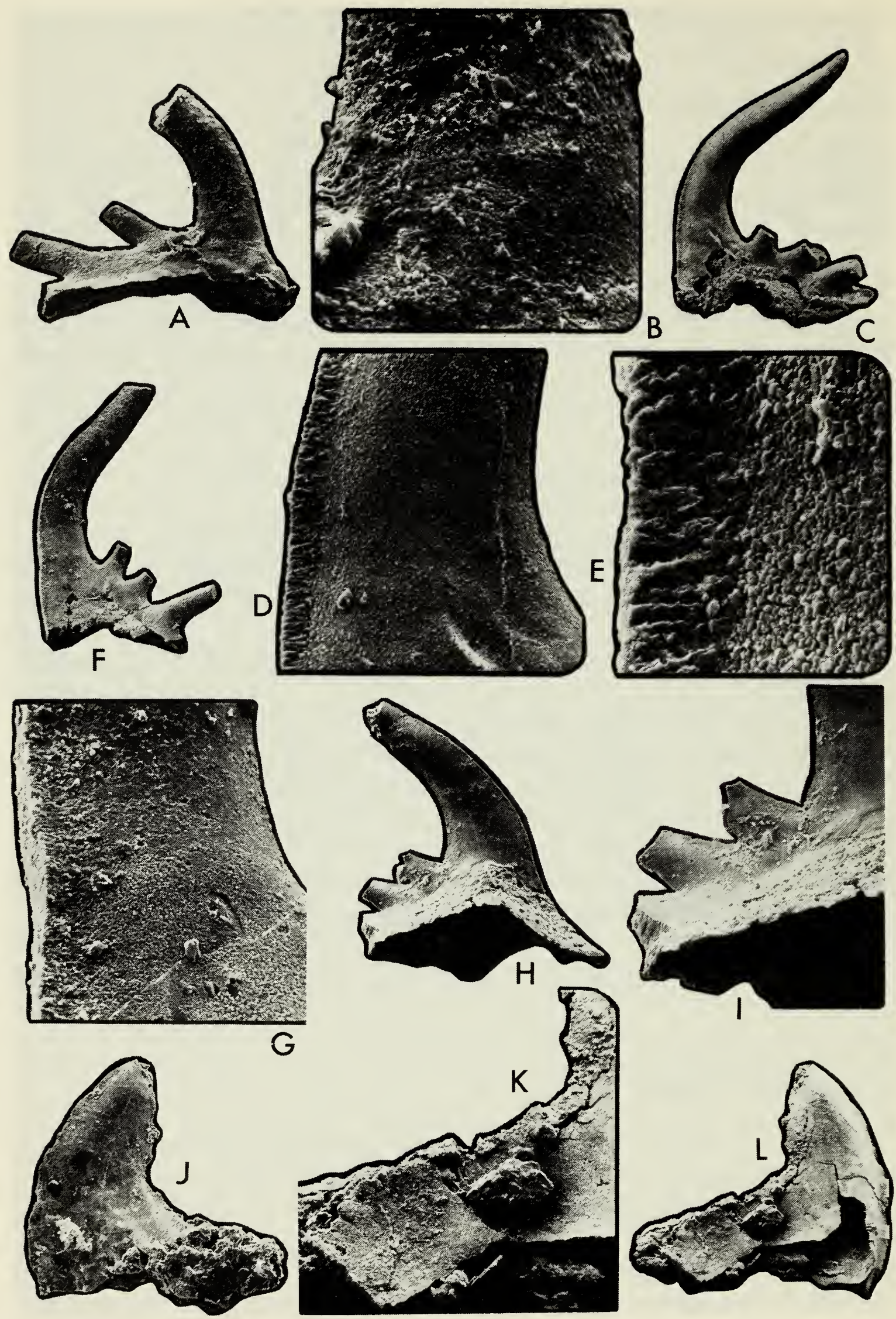
Cordylodus prion prion Nowlan, 1976:154-156, pl. 2, figs. 23-31.

Cordylodus oklahomensis-Landing, 1979:64, 65, 135, 136, pl. II-3, fig. 5, pl. III-1, fig. 10.

\section{Occurrence}

A total of 105 cordylodiform and 29 cyrtoniodiform elements from the uppermost Cambrian and lowest Ordovician of Section KK (Parabolina Fauna through Apoplanias Fauna).

\section{Hypotypes}

Cordylodiform elements ROM 38371 and ROM 38372 from KK 124 and cyrtoniodiform element ROM 38367 from KK 122.5 .

\section{Description}

The component form species Cordylodus proavus and $C$. oklahomensis have been adequately redescribed by Miller (1969) and only remarks are presented here. Cordylodiform elements have discrete denticles and cusp which have well rounded to laterally flattened cross sections. A rounded carina may be present on the anterior and posterior edges of the cusp (Figs. $6 \mathrm{C}-\mathrm{G}$ ), and the anterior margin may be laterally deflected (Figs. 6F, G). Cyrtoniodiform elements have basally confluent denticles and, generally, a lateral flaring of the base under the cusp (Figs. 6H, I).

Crystallites present in Cordylodus elements apparently are oriented radially to the surface of the element. Edges or keels are formed by the elongation of these crystallites along the anterior margin of the cusp (Figs. 6C-G).

Fig. 6A, B Cordylodus intermedius Furnish s.f., ROM 38373, sample KK 33.

A Lateral view, $\times 120$.

B Detail of slightly etched surface, $\times 602$.

C-E Cordylodus oklahomensis Müller, cordylodiform element, ROM 38371, sample KK 124.

C Lateral view, $\times 60$.

D, E Detail of anterior carina showing orientation of crystallites, $\times 301$ and $\times 1204$, respectively.

F, G Cordylodus oklahomensis Müller, cordylodiform element, ROM 38372, sample KK 124.

F Lateral view of asymmetrical element, $\times 60$.

G Detail of slightly etched surface and anterior carina, $\times 301$.

H, I Cordylodus oklahomensis Müller, cyrtoniodiform element, ROM 38367, sample KK 122.5.

H Inner lateral view of element with attached basal plate, $\times 65$.

I Detail showing contrasting surface texture of smooth conodont element and porous basal plate, $\times 129$.

J-L Fryxellodontus? sp. nov., serrated element, ROM 38366, sample KK 146.

$\mathrm{J}, \mathrm{L} \quad$ Lateral views, $\times 52$.

$\mathrm{K} \quad$ Right-lateral view showing denticulated oral edge of broken distal end of posterior process, $\times 103$. 


\section{Remarks}

Cordylodus proavus s.f. and C. oklahomensis s.f. are considered to be the component form species of multi-element $C$. oklahomensis. The two form species have a comparable stratigraphic range (Miller, 1969:426). Both elements appear at the same stratigraphic level in Utah (Miller, 1978) and Vermont (Landing, 1979), and co-occur in the same samples in Iran (Müller, 1973). The two form species also have nearly coincident ranges in Alberta (Derby et al., 1972) with C. oklahomensis s.f. first recovered less than a metre above the lowest occurrence of $C$. proavus s.f. Similarly, $C$. proavus s.f. and "C . prion prion" (=C. oklahomensis $s . f$.) of Nowlan (1976) first appear at the same level in the Copes Bay Formation in the Canadian Arctic and have similar stratigraphic ranges.

Druce and Jones (1971, see also Druce, 1978) described a stratigraphic overlap of Cordylodus oklahomensis $s . f$. only in the upper portion of the local range zone of $C$. proavus s.f. However, this stratigraphic non-concordance is probably related to the small number of specimens recovered. The illustrated specimens of $C$. oklahomensis s.f. from Australia (Druce and Jones, 1971) are apparently the cyrtoniodiform elements of multi-element $C$. intermedius.

Proconodontus notchpeakensis $s . f$. and $\boldsymbol{P}$. carinatus $\boldsymbol{s}$.f. are the apparent "ancestors', respectively, of Cordylodus proavus s.f. and C. oklahomensis s.f. (Miller, $1969,1970)$. The similarity of the elements in bi-element "Proconodontus" carinatus (discussed below) to those of multi-element $C$. oklahomensis also suggests a comparable apparatus construction in the two species.

Cordylodus proavus s.f. appears to have been numerically dominant over C. oklahomensis s.f. in the $C$. oklahomensis apparatus. Miller (1978) recovered the elements in the ratio 3287:781 at the Lava Dam North section in Utah. A closely similar ratio 105:29 occurs in the Rabbitkettle collection. These data suggest that the elements occurred in the ratio 4:1 in a $C$. oklahomensis apparatus and that a minimum number of 10 elements was present in a bilaterally symmetrical $C$. oklahomensis animal.

\section{Genus Fryxellodontus Miller, 1969}

\section{Type Species}

Fryxellodontus inornatus Miller, 1969, from the Notch Peak Limestone, House Range, west-central Utah.

\section{Fryxellodontus inornatus Miller, 1969}

Figs. 7C-G

Fryxellodontus inornatus Miller, 1969:426, 428, 429, pl. 65, figs. 1-10, 12-16, 23-25, text-figs. 4A, C, D, E (pars).

Fryxellodontus inornatus-Miller, 1970:97, text-figs. 10Q-T.

Gen. et sp. indet. B Druce and Jones, 1971:102, pl. 12, figs. 9a, b, text-fig. 33.

Fryxellodontus inornatus-Nowlan, 1976:237, pl. 1, figs. 17-19. 


\section{Occurrence and Hypotype}

One symmetricus element (ROM 38368) from the Apoplanias Fauna, sample KK 43.

\section{Remarks}

Miller (1969) has provided a thorough description of the elements of the Fryxellodontus inornatus apparatus. An additional observation is that the elements lack surficial microsculpture when examined with the scanning electron microscope (Fig. 7C, D, G).

The element recovered from Section $\mathrm{KK}$ is composed of acicular crystallites oriented perpendicular to the surface of the specimen (Fig. 7E, F).

\section{Fryxellodontus? sp. nov.}

Fig. 5B, 6J-L, 7A, B

\section{Occurrence and Hypotype}

One element (ROM 38366) from the Bowmania americana Fauna (KK 146).

\section{Description}

A strongly laterally flattened, completely hollow, sheathlike element with a denticulated posterior process which is much longer than the blunt cusp. A smooth, open arc is formed by the posterior edge of the cusp and the oral edge. Lateral displacement of the anterior keel and slight concavity of the right-lateral surface produce asymmetry in the element.

\section{Remarks}

The element is completely hollow and lacks any surface microsculpture. It has some similarity to the planus and serratus elements of Fryxellodontus inornatus (Miller, 1969) although a long posterior process is present. This posterior process, which was broken in preparation, is distally denticulated (Fig. $6 \mathrm{~K}, \mathrm{~L}$ ).

It is uncertain whether the element actually represents a species of Fryxellodontus because associated elements of the apparatus were not recovered. However, if the element does belong to the genus, it is the only known Upper Cambrian representative of the genus.

\section{Genus Furnishina Müller, 1959}

\section{Type Species}

Furnishina furnishi Müller, 1959, s.f. from the Gallatin Limestone, Big Horn Mountains, Wyoming. 

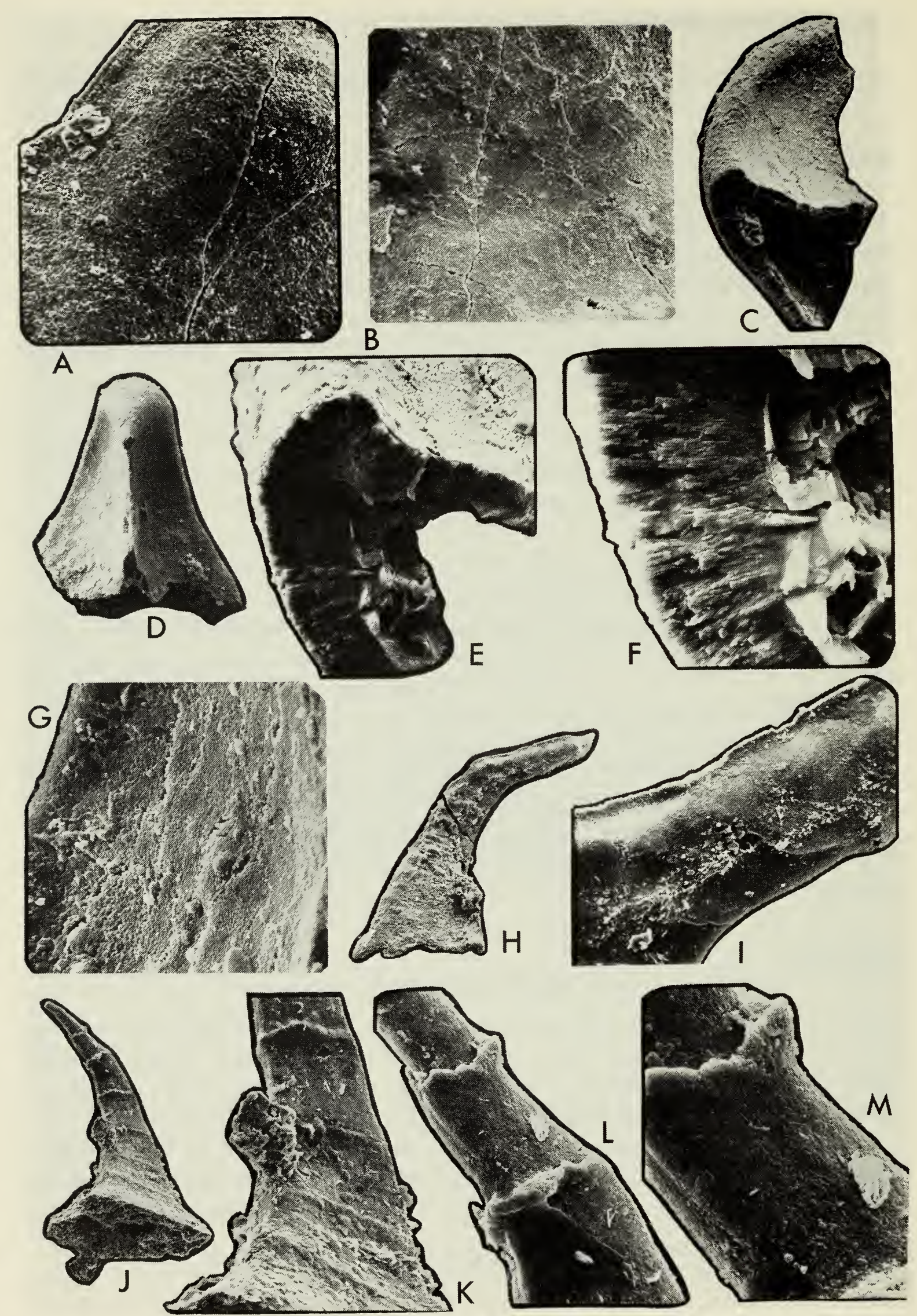


\section{Furnishina asymmetrica Müller, 1959 s.f.}

Figs. 7J-M

Furnishina asymmetrica Müller, 1959:451, 452, pl. 11, figs. 16a, b, 19.

Furnishina asymmetrica-Nogami, 1966:354, pl. 9, figs. 1a-2b.

Furnishina asymmetrica-Müller, 1971:8, pl. 1, figs. 13, 16.

Furnishina asymmetrica-Müller, 1973:39, pl. 1, figs. 6, 8, 9.

Furnishina asymmetrica-Lee, 1975:79, pl. 1, fig. 1, text-fig. 2A.

Furnishina asymmetrica-Miller and Paden, 1976:595, pl. 1, figs. 13, 14.

Furnishina asymmetrica-Abaimova, 1978:78, pl. 7, fig. 1 .

Furnishina asymmetrica-Landing, 1979:22, pl. I-1, fig. 7.

\section{Occurrence and Hypotype}

One element (ROM 38374) from the Cordylodus oklahomensis Zone (KK 33). Trilobites of the Apoplanias Fauna and Symphysurina brevispicata Subzone were recovered, respectively, below (KK 43) and above (KK 25) sample KK 33.

\section{Remarks}

Furnishina asymmetrica s.f. and $F$. furnishi Müller are probably asymmetrical and subsymmetrical to symmetrical elements of the $F$. furnishi apparatus (Landing, 1979).

Paraconodont structure, or the aboral addition of growth lamellae which do not enclose the distal portion of the element (Bengtson, 1976), is shown by the detachment of the distal portion of growth lamellae from previously secreted portions of the sclerite (Figs. $7 \mathrm{~K}-\mathrm{M}$ ).

Fig. 7A, B Fryxellodontus? sp. nov., serrated element, ROM 38366, sample KK 146.

A Detail of posterolateral margin of cusp showing prismatic crystallites comprising posterior carina (compare Fig. 6L), $\times 269$.

B Detail of lateral surface of cusp showing slightly corroded surface of originally smooth element (compare Fig. 6J), $\times 269$.

C-G Fryxellodontus inornatus Miller, symmetrical element, ROM 38368, sample KK 43.

C Aboral-lateral view (note broken tip of element, compare Fig. 7D), $\times 215$

D Posterior view, $\times 151$.

E, F Detail of crystallites oriented normal to wall of element (compare Fig. 7c), $\times 731$ and $\times 1462$, respectively.

G Detail of corroded outer surface of originally smooth element (compare Fig. 7D), $\times 753$.

H, I Protoconodont sp. indet. s.f., ROM 38375, sample KK* 135-I50.

H Lateral view, $\times 47$.

I Detail showing lower edges of basally-internally secreted lamellac, $\times 237$.

J-M Furnishina asymmetrica Müller, s.f., ROM 38374, sample KK 33.

J Posterior view, $\times 99$.

K-M Detail of surface of element showing exfoliation of upper portions of paraconodont growth lamellae, $\times 290, \times 247, \times 989$, respectively. 


\section{Genus Oneotodus Lindström, 1955}

\section{Type Species}

Distacodus? simplex Furnish, 1938, s.f. from the Oneota Dolostone, Allamakee County, Iowa.

\section{"Oneotodus" nakamurai Nogami, 1967}

Fig. $8 \mathrm{~A}-\mathrm{C}$

Oneotodus sp. A. Müller, 1959:458, pl. 13, fig. 17.

Oneotodus nakamurai Nogami, 1967:216, 217, pl. 1, figs. 9a-13, text-figs. 3A-E.

Oneotodus nakamurai-Miller, 1969:435, 436, pl. 63, figs. 1-9, text-fig. 5E (pars, pl. 63, fig. $10=$ "Acodus" sevierensis Miller, 1969 s.f.).

Oneotodus simplex-Miller, 1970:101, 102, text-fig. 9D (non O. simplex Furnish, 1938, s.f.).

Oneotodus sp. aff. simplex-Miller, 1970:102, text-fig. 9E (non O. simplex [Furnish, 1938] s.f.).

Oneotodus datsonensis Druce and Jones, 1971:80, pl. 14, figs. 1a-3b, text-fig. 26c (pars, pl. 14, figs. 4a, b = "Acodus" housensis Miller, 1969, s.f.).

Oneotodus nakamurai-Druce and Jones, 1971:82, 83, pl. 10, figs. 3a-5c, 7a-8b, text-fig. 26i (pars, pl. 10, figs. 1, 2, 6a-c, text-fig. 26j = Proconodontus notchpeakensis Miller, 1969, s.f.).

Fig. 8A-C “Oneotodus" nakamurai Nogami, ROM 38370, sample KK* 135-150.

Lateral view of long-based element, $\times 95$.

Detail of subparallel striae (compare Fig. 8 A), $\times 946$.

Detail of subparallel striae (centre of Fig. 8 B), $\times 2365$.

D, E “Proconodontus" carinatus Miller, scandodiform element, ROM 38362, sample KK 119.5.

D Inner lateral view of aborally flaring side, $\times 129$.

E Corroded surface or originally smooth element, $\times 645$.

F "Proconodontus" carinatus Miller, drepanodiform element, ROM 38365, sample KK 50, $\times 52$.

G, H “Proconodontus" carinatus Miller, drepanodiform element, ROM 38369, sample KK 43.

G Lateral view, $\times 108$.

H Detail of corroded surface of originally smooth element, $\times 538$.

I-L Proconodontus serratus Miller s.f., ROM 38363, sample KK 86.5.

I, J Lateral views, $\times 52$ and $\times 49$, respectively.

$\mathrm{K}$ Detail showing acicular crystallites composing denticulated oral edge (compare Fig. $8 \mathrm{I}), \times 258$.

L Detail showing acicular crystallites comprising anterior carina (compare Fig. 8J), $\times 247$.

M, N “Prooneotodus" tenuis (Müller), ROM 38364, sample KK 77.

M Detail showing irregular lower (aboral) edges of basal, internally accreted, growth lamellae, $\times 58$.

$\mathrm{N}$ Anterior or posterior view of three-element incomplete half-apparatus (Landing, 1977). Third (lower) element largely obscured by upper two elements, $\times 581$.

o Phosphannulus universalis Müller, Nogami, and Lenz, ROM 38361, sample KK 123. Oblique view of attachment surface, $\times 112$. 

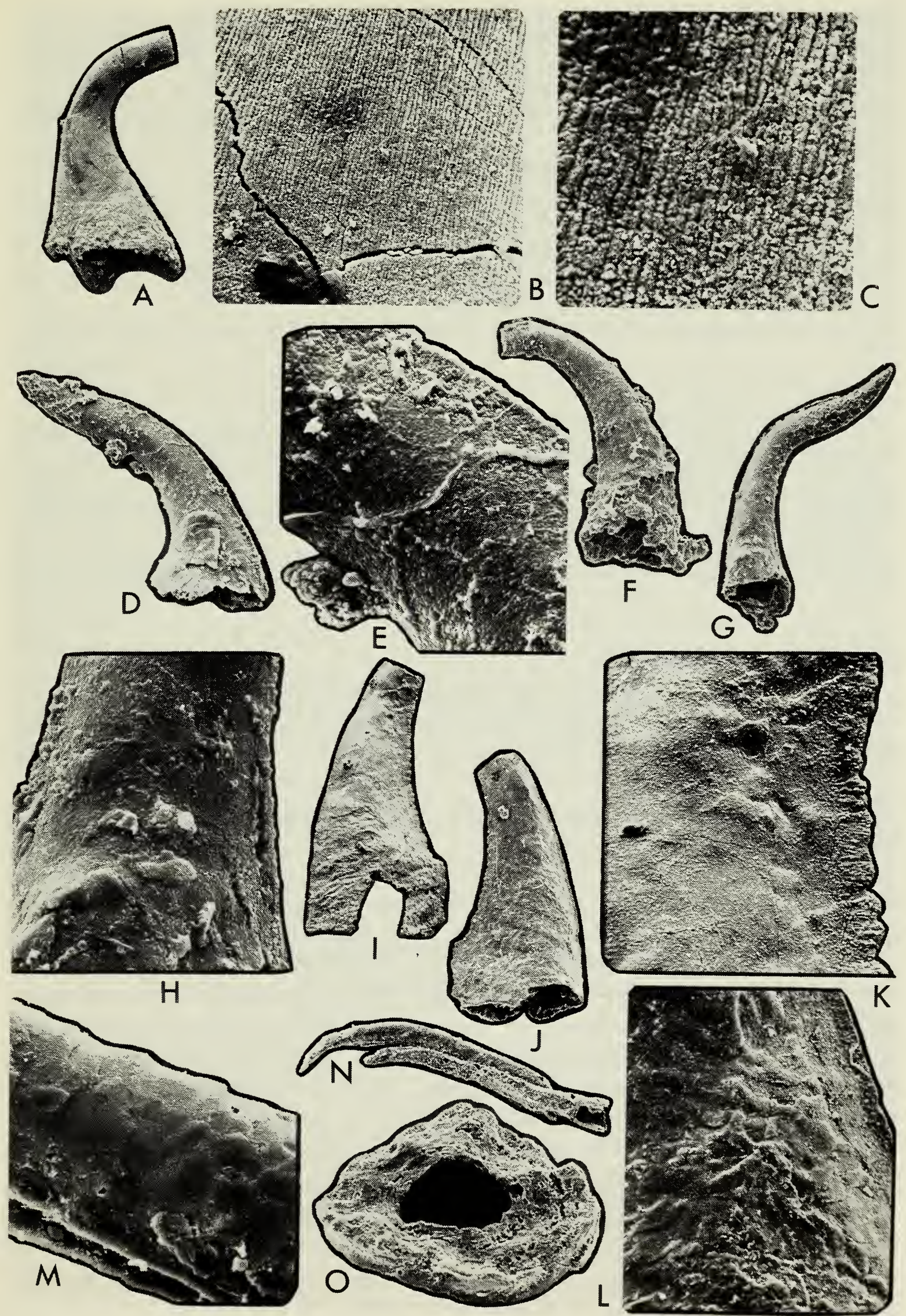
Oneotodus datsonensis-Jones, 1971:56, 57, pl. 3, figs. 5a-c, 7a-c.

Oneotodus nakamurai-Jones, 1971:58, pl. 4, figs. 1a-c, 3a-4c (pars, pl. 4, figs. 2a-c = "Acontiodus" unicostatus Miller, 1969, s.f.).

Oneotodus sp. aff. simplex-Miller and Melby, 1971:122, pl. 2, fig. 9 (non O. simplex [Furnish, 1938] s.f.).

Oneotodus nakamurai-Müller, 1971:10, text-fig. le.

Oneotodus nakamurai-Müller and Nogami, 1971:76, pl. 7, fig. 1, text-fig. 14B.

Oneotodus nakamurai-Müller, 1973:41, pl. 5, fig. 4.

Oneotodus nakamurai-Lee, 1975:81, pl. 1, figs. 6, 9, 10, text-figs. 2E, G.

Oneotodus nakamurai-Nowlan, 1976:294, 295, pl. 1, figs. 24-28.

Oneotodus nakamurai-Abaimova and Markov, 1977:92, 93, pl. 14, figs. 12-14, 16.

Oneotodus variabilis-Abaimova and Markov, 1977:93, pl. 14, fig. 11, pl. 15, fig. 4 (non O. variabilis Lindström, 1955, s.f.).

"'Oneotodus" nakamurai-Landing, 1979:72, 73, 146, 147, 206, 207, pl. II-2, figs. $13-15,17$, pl. III-1, figs. 6,7 , pl. IV-1, figs. 8, 9 .

Oneotodus simplex-Tipnis et al., 1979:31, pl. 1, fig. 18 (non O. simplex [Furnish, 1938] s.f.).

Oneotodus variabilis Lindström, Tipnis et al., 1979:31, pl. 1, figs. 20, 22.

\section{Occurrence and Hypotype}

Two elements from the Bowmania americana Fauna, samples KK* 135-150 (ROM 38370) and KK 78 (specimen lost).

\section{Remarks}

Miller (1969) restricted his concept of Oneotodus nakamurai to elements with a length: width ratio of the basal margin of 2:3 to 3:2. He assigned one of Nogami's figured specimens (Nogami, 1967: pl. 1, fig. 13) to Semiacontiodus nogamii Miller because of the strong anteroposterior flattening of the aboral margin of the element. Miller's (1969) taxonomic restriction stems from a failure to recover the species below the Cordylodus oklahomensis Zone. Landing (1979) noted that "O." nakamurai elements from the upper Proconodontus Zone in Vermont and New York tend to have longer bases than those from higher strata. In addition, "O." nakamurai elements with long bases from the Proconodontus Zone are often strongly aborally flattened or have a rounded triangular cross section of the aboral margin (Landing, 1979). The narrowly rounded anterolateral and oral margins of the illustrated specimen from the Rabbitkettle produce a triangular aboral cross section (Fig. 8A).

\section{Discussion}

"Oneotodus" nakamurai specimens are covered with fine, subparallel striations (Fig. 8B, C) and are consequently unique among conodont elements from Proconodontus and lower Cordylodus oklahomensis zones. The restriction of this surface microstructure to " $O$." nakamurai suggests that the apparatus is mono-elemental. 
Although "Oneotodus" nakamurai elements may appear to be similar to Proconodontus notchpeakensis Miller s.f. (Miller, 1969:436), the latter are devoid of surface microsculpture (Landing, 1979; this report). "Oneotodus" nakamurai appears in uppermost Cambrian faunas without known ancestors. Long-based elements in the Proconodontus Zone are replaced by short-based forms in the Cordylodus oklahomensis Zone (Landing, 1979). These short-based elements were apparently ancestral to upper C. oklahomensis Zone forms such as Miller's (1969) "Acodus" housensis s.f., "A." sevierensis s.f., Semiacontiodus, and "Paltodus" utahensis Miller, 1969 s.f., all of which are finely striated and albid (Landing, 1979).

\section{Taxonomy}

"Oneotodus" nakamurai elements are provisionally referred to Oneotodus. R. L. Ethington (pers. comm., 1979) notes that elements of the type species, $O$. simplex, have low lateral costae, a shallower basal cavity than that illustrated by Furnish (1938), and coarser striae than forms referred by other authors to Oneotodus. The basal cavity of " $O$." nakamurai extends to the point of maximum curvature of the finely striated element.

\section{Genus Proconodontus Miller, 1969}

\section{Type Species}

Proconodontus muelleri Miller, 1969, from the Notch Peak Limestone, House Range, west-central Utah.

\section{"Proconodontus" carinatus Miller, 1969}

Fig. 5C, F, 8D-H

\section{Drepanodiform Element}

Oneotodus sp. indet. Müller, 1959:458, pl. 13, fig. 15.

Proconodontus notchpeakensis Miller, 1969:458, pl. 66, figs. 21-29, text-fig. 5G.

Proconodontus notchpeakensis-Miller, 1970:105, 106, text-fig. 9M.

Oneotodus gallatini-Druce and Jones, 1971:81, 82, pl. 9, figs. 9a-c, pl. 10, figs. 9a-10c, text-figs. 26f, g (non Proconodontus gallatini [Müller, 1959] s.f.).

Proconodontus notchpeakensis-Müller, 1971:43, pl. 4, fig. 6.

Oneotodus nakamurai-Lee, 1975:81, (pars, pl. 1, fig. 9, non 'O." nakamurai Nogami, 1966).

Proconodontus notchpeakensis-Nowlan, 1976:351, pl. 1, figs. 6, 7.

"Proconodontus" carinatus-Landing, 1979:78, 151, 152, 209, pl. II-3, fig. 12, pl. III-1, fig. 16, pl. IV-1, figs. 10, 11 (pars, cited figures are only of drepanodiform element). 
Proconodontus notchpeakensis-Tipnis et al., 1979:31, pl. 1, fig. 14.

?Proconodontus cf. P. notchpeakensis-Tipnis et al., 1979:31, pl. 1, fig. 15.

\section{Scandodiform Element}

Proconodontus carinatus Miller, 1969:437, pl. 66, figs. 13-20, text-fig. 51.

Proconodontus carinatus-Miller, 1970:104, text-fig. 5I.

Proconodontus carinatus-Miller and Melby, 1971:122, pl. 2, figs. 16, 17.

Proconodontus aff. carinatus-Ozgül and Gedik, 1973:49, pl. 1, fig. 15.

Proconodontus carinatus-Nowlan, 1976:349, pl. 1, figs. 11, 12.

Proconodontus carinatus-Landing et al., 1978:76, fig. 2 A.

Proconodontus carinatus-Landing, 1979:24, pl. I-1, fig. 8.

"Proconodontus" carinatus-Landing, 1979:78, 204, pl. II-3, fig. 9, pl. IV-1,

fig. 14 (pars, cited figures are only of scandodiform element).

\section{Occurrence}

Thirteen scandodiform and 41 drepanodiform elements recovered in association with Bowmania americana Fauna through Apoplanias Fauna trilobites. A scandodiform element from KK* 0-12 occurs above the highest known trilobites (Symphysurina brevispicata Subzone) from KK 20.

\section{Hypotypes}

Scandodiform hypotype ROM 38362 from KK 119.5 and drepanodiform hypotypes ROM 38365 and 38369 from KK 50 and KK 43, respectively.

\section{Remarks}

Proconodontus carinatus s.f. and $P$. notchpeakensis s.f. have basal cavities which do not extend to the tip of the elements, and the cusps are albid above the basal cavity. The two form species differ from the completely hollow elements of $P$. muelleri s.f. and $P$. serratus $s . f$. although all four form species lack any surface microsculpture (Landing, 1979).

Proconodontus carinatus $s . f$. and $P$. notchpeakensis $s . f$. regularly appear together at the base of the $P$. notchpeakensis Subzone (Miller, 1970; Derby et al., 1972) and persist into Fauna B (Miller, 1970, 1978). The two form species regularly occur together in continental slope deposits in the Appalachians (Landing, 1979). Similarity of range zones and regular association suggests that the two elements are part of a multi-element species (Miller, 1978; Landing, 1979). Proconodontus notchpeakensis $s . f$. and $P$. carinatus $s . f$. represent the bilaterally symmetrical (drepanodiform) and the aborally laterally flared (scandodiform) elements of the apparatus. These two elements are homologous, respectively, to the cordylodiform and cyrtoniodiform elements of bi-elemental Cordylodus oklahomensis. A further similarity between these two apparatuses is that the bilaterally symmetrical to subsymmetrical drepanodiform 
and cordylodiform elements are numerically dominant. However it is possible that the element ratio differs between the two species. Miller (1978) recovered the elements in a drepanodiform:scandodiform ratio of 3837:1471 (1:0.38) at the Lava Dam Five section in the Notch Peak Limestone, Utah. The ratio in the sparse Rabbitkettle collection is $41: 13(1: 0.32)$. These data suggest that scandodiform elements were proportionately better represented in "Proconodontus" carinatus than the corresponding cyrtoniodiform elements in Cordylodus oklahomensis.

"Proconodontus" carinatus is here provisionally referred to Proconodontus. The elements of this bi-elemental apparatus differ strongly from the type species Proconodontus muelleri s.f. In addition, the $P$. muelleri apparatus appears to have been mono-elemental (Landing, 1979).

\section{Proconodontus serratus Miller, 1969, s.f.}

Fig. 8I-L

Proconodontus mülleri serratus Miller, 1969:438, pl. 66, figs. 41-44.

Proconodontus muelleri serratus-Miller, 1969:105, text-fig. 9L.

Coelocerodontus burkei Druce and Jones, 1971:61, 62, pl. 11, figs. 5a-6c, 8a-c, text-fig. 22e (pars, pl. 11, figs. 7a-c, 9-12b, text-fig. 22a = Proconodontus muelleri Miller, 1969, s.f.).

Proconodontus serratus-Müller, 1973:44, pl. 4, figs. 1a-2.

Proconodontus serratus-Landing, 1979:79, 80, 153, 210, 211, pl. II-3, fig. 16, pl. III-1, fig. 4, pl. IV-1, figs. 12, 15.

\section{Occurrence and Hypotype}

Recovered from the Bowmania americana Fauna, sample KK 86.5 (two elements) and KK* 135-150 (one element). Hypotype ROM 38363 from KK 86.5.

\section{Remarks}

Proconodontus muelleri Miller, $s . f$. and $P$. serratus $s . f$. have basal cavities reaching almost to the tip of the elements, differ in the serrated posterior edge of the latter (Miller, 1969), and lack surface microsculpture (Landing, 1979). The posterior edge of $P$. serratus s.f. may be almost completely serrated (Fig. 8I, J) or may have only a few denticles near the aboral margin or distally (Landing, 1979). The co-occurrence of $P$. muelleri s.f. and P. serratus in the upper Saukia Zone (Miller, 1969-1978; Landing, 1979) may mean that one conodont animal bore both types of elements. The absence of $P$. serratus s.f. in the lower Saukia Zone (Miller, 1975, 1977) possibly means that denticulation has not appeared in some of the elements of an essentially mono-elemental $P$. muelleri apparatus.

Dissolution of the surface of the elements from Section KK reveals that the anterior carina (Fig. 8L) and posterior serrated edge (Fig. 8K) are comprised of acicular crystallites oriented parallel to the plane of lateral flattening of the elements. 


\section{Genus Prooneotodus Müller and Nogami, 1971}

\section{Type Species}

Oneotodus gallatini Müller, 1959, s.f. from the Gallatin Limestone, Big Horn Mountains, Wyoming.

\section{“Prooneotodus” tenuis (Müller, 1959)}

Fig. 8M, N

Oneotodus tenuis Müller, 1959:457, 458, pl. 13, figs. 11, 13, 14, 20.

Oneotodus tenuis-Nogami, 1966:356, pl. 9, figs. 11, 12.

Oneotodus tenuis-Clark and Robison, 1969:1045, text-fig. 1a.

Oneotodus tenuis-Miller, 1969:436, pl. 64, figs. 43-45, text-fig. 5C.

Oneotodus tenuis-Müller, 1971:8, pl. 1, figs. 1a, v, 4-6.

Prooneotodus tenuis-Müller, 1973:45, pl. 1, figs. 1-36.

Oneotodus tenuis-Ozgül and Gedik, 1973:48, pl. 1, figs. 2, 10, 12.

Prooneotodus tenuis-Lee, 1975:83, 84, pl. 1, figs. 14-17, text-figs. $2 \mathrm{~K}, \mathrm{~L}$.

Prooneotodus tenuis-Miller and Paden, 1976:596, pl. 1, figs. 20-23.

Prooneotodus tenuis-Müller and Andres, 1976:193-200, pl. 22, figs. A, B, textfigs. 1a-3.

"Prooneotodus" tenuis-Landing, 1977:1072-1084, pl. 1, fig. 1-9, pl. 2, figs. $1-11$, text-fig. 1

"Prooneotodus" tenuis-Landing et al., 1978:76, text-fig. 2B.

Prooneotodus tenuis-Abaimova, 1978:83, pl. 8, figs. 2, 4, 9.

Prooneotodus savitskyi Abaimova, 1978:82, 83, pl. 7, figs. 13, 14, pl. 8, fig. 1.

“Prooneotodus"' tenuis-Landing, 1979:25, 82, 83, 153, 154, 212, 225-250, pl. I-1, fig. 12, pl. II-3, fig. 18, pl. III-1, fig. 3, pl. IV-1, fig. 3, pl. V-1, figs. $1-9$, pl. V-2, figs. 1-11, text-fig. V-1.

Oneotodus tenuis-Tipnis et al., 1979:31, pl. 1, fig. 6.

\section{Occurrence and Hypotype}

Two elements from the Missisquoia depressa Subzone, samples KK 50 and KK 116, and the hypotype (ROM 38364) three element incomplete half-apparatus (Landing, 1977) from the Bowmania americana Fauna, sample KK 77.

\section{Remarks}

The elements of "Prooneotodus" tenuis have protoconodont structure and the species cannot be brought to the paraconodont genus Prooneotodus (Landing, 1977).

Dissolution of the exterior surface of the elements from Section KK has apparently obscured the fine longitudinal striations present in elements of the species (Müller, 1971; Landing, 1977) and caused irregular exfoliation of the growth lamellae (Fig. 8M). 


\section{Protoconodont sp. indet. $s . f$.}

Fig. 5G, 7H, I

?Furnishina? sp. Tipnis et al., 1979:31, pl. 1, fig. 5.

\section{Occurrence and Hypotype}

Two specimens (hypotype ROM 38375) from the Bowmania americana Fauna $\left(\mathrm{KK}^{*} 135-150\right)$.

\section{Description}

The form is known from gently curved, asymmetrical, conelike, proclined elements with sharp posterior costa. The anterior costa becomes rounded aborally and a rounded anterolateral costa is present. The internal cavity extends nearly to the end of the thin-walled elements.

\section{Remarks}

The specimens have a superficial resemblance to the euconodont Proconodontus muelleri Miller s.f. and to the paraconodont Furnishina primitiva Müller s.f. However, examination of the surface of the elements (Fig. 5I) shows that they grew by basal-internal addition of growth lamellae and have protoconodont structure (Bengtson, 1976).

Tipnis et al. (1979) illustrated a similar element from section K (sample K 525).

\section{Order Hyolithelminthes Fisher, 1962 \\ Family Phosphannulidae Müller, Nogami, and Lenz, 1974 \\ Genus Phosphannulus Müller, Nogami, and Lenz, 1974}

\section{Type Species}

Phosphannulus universalis Müller, Nogami, and Lenz from the Upper Silurian Beyrichien-Kalke, Berlin Spandau-West.

\section{Phosphannulus universalis Müller, Nogami, and Lenz, 1974}

Fig. 80

Form B Webers, 1966:72, pl. 14, figs. 3, 6.

Phosphannulus universalis Müller, Nogami, and Lenz, 1974:91, 92, pl. 18, figs. $1-12$, pl. 19 , figs. $1-13$, pl. 20 , figs. $1-7$, pl. 21 , figs. $1-9$, text-figs. $1-6$. Phosphannulus sp. Winder, 1976:654, pl. 2, fig. 11.

Phosphannulus universalis-Landing, 1979:28, 215, pl. I-1, fig. 2, pl. IV-1, fig. 7. 


\section{Occurrence and Hypotype}

Recovered from the Yukonaspis kindlei Fauna through Missisquoia sp. nov. Fauna. Four specimens from KK 33 occur in an interval lying below the Symphysurina brevispicata Subzone and above the Apoplanias Fauna. Hypotype ROM 38361 from the Missisquoia sp. nov. Fauna (KK 123).

\section{Remarks}

The form, an attachment structure secreted by a possible hyolithelminthoid epizoan (Müller et al., 1974), ranges from the Late Cambrian through Late Devonian. It has been reported from North America, Iran, and Baltoscandia. 


\section{Acknowledgements}

Landing studied the conodont faunas of this report as a post-doctoral fellow at the University of Waterloo with Dr. C. R. Barnes as supervisor. Ludvigsen's field work was supported by a grant from the Natural Sciences and Engineering Research Council. Mr. Peter Fenton, University of Toronto, ably assisted in the field. Dr. C. R. Barnes reviewed the preliminary manuscript. The electron microscopy was done by Mr. George Gomolka, Department of Geology, University of Toronto.

We are grateful to all of the individuals mentioned above. We also thank the two reviewers whose critical comments improved the paper. 


\section{Literature Cited}

ABAIMOVA, G.P.

1975 Early Ordovician conodonts from the middle reaches of the Lena River. Transaction Series of the Siberian Scientific Research Institute for Geology, Geophysics and Mineralogy, Novosibirsk, 207:1-129. [In Russian].

1978 First Cambrian conodonts from the central region of Kazakhstan. Paleontological Journal 17:77-87. [In Russian].

ABAIMOVA, G.P. and Ye. P. MARKOV

1977 First recovery of conodonts of the lowest Ordovician Cordylodus proavus Zone on the southern Siberian Platform. In Sokolov, V.S. and A.V. Kanygin, eds., Stratigraphic problems of the Ordovician and Silurian of Siberia. Transactions of the Institute of Geology and Geophysics, Academy of Sciences SSSR, Siberian Section, Novosibirsk, 372:86-94. [In Russian].

BARNES, C.R. and M.L.S. POPLAWSKI

1973 Lower and Middle Ordovician conodonts from the Mystic Formation, Quebec, Can. ada. Journal of Paleontology 47:760-790.

BARNES, C.R., C.B. REXROAD, and J.F. MILLER

1973 Lower Paleozoic conodont provincialism. In Rhodes, F.H.T., ed., Conodont paleozoology. Geological Society of America, Special Paper 141:157-190.

\section{BENGTSON, S}

1976 The structure of some Middle Cambrian conodonts, and the early evolution of conodont structure and function. Lethaia 9:185-206.

BERGSTRÖM, S.M. and W.C. SWEET

1966 Conodonts from the Lexington Limestone (Middle Ordovician) of Kentucky and its lateral equivalents in Ohio and Indiana. Bulletins of American Paleontology 50:271-441.

CECILE, M.P.

1978 Report on Road River stratigraphy and the Misty Creek Embayment, Bonnet Plume (106B), and surrounding map-areas, Northwest Territories. Geological Survey of Canada, Paper 78-1 A:371-377.

CLARK, D.L. and R.A. ROBISON

1969 Oldest conodonts in North America. Journal of Paleontology 40:1044-1046.

COOK, H.E.

1972 Miette platform evolution and relation to overlying bank ("reef") localization, Upper Devonian, Alberta. Bulletin of Canadian Petroleum Geology 20:375-411.

DERBY, J.R., H.R. LANE, and B.S. NORFORD

1972 Uppermost Cambrian-basal Ordovician faunal succession in Alberta and correlation with similar sequences in the western United States. 24th International Geological Congress, Montreal, 1972, Proceedings 7:503-512.

DRUCE, E.C.

1978 Correlation of the Cambrian/Ordovician boundary in Australia. In Belford, B.J. and V. Scheibnerova, eds., The Crespin volume: essays in honour of Irene Crespin. Australia Bureau of Mineral Resources, Geology and Geophysics, Bulletin 192:49-60.

DRUCE. E.C. and P.J. JONES

1971 Cambro-Ordovician conodonts from the Burke River structural belt, Queensland. Australia Bureau of Mineral Resources, Geology and Geophysics, Bulletin 110:1-167.

EICHENBERG, W.

1930 Conodonten aus dem Culm des Harzes. Paläontologische Zeitschrift 12:177-182. 
EPSTEIN, A.G., J.B. EPSTEIN, and L.D. HARRIS

1977 Conodont color alteration-an index to organic metamorphism. United States Geological Survey Professional Paper 995:1-27.

ETHINGTON, R.L. and D.L. CLARK

1971 Lower Ordovician conodonts of North America. In Sweet, W.C. and S.M. Bergström, eds., Symposium on conodont biostratigraphy. Geological Society of America, Memoir $127: 21-61$.

FÅHRAEUS. L.E. and G.S. NOWLAN

1978 Franconian (Late Cambrian) to Early Champlainian (Middle Ordovician) conodonts from the Cow Head Group, western Newfoundland. Journal of Paleontology 52:444-471.

FISHER, D.W.

1962 Small conoidal shells of uncertain affinities. In Moore, R.C., ed., Treatise on Invertebrate Paleontology, Part W, Miscellanea. Lawrence, Geological Society of America and University of Kansas Press, pp. W98-W143.

FORTEY, R.A.

1975 Early Ordovician trilobite communities. In Martinsson, A., ed., Evolution and morphology of the Trilobita, Trilobitoidea and Merostomata. Fossils and Strata 4:331-352.

FURNISH, W.M

1938 Conodonts from the Prairie du Chien (Lower Ordovician) beds of the Upper Mississippi Valley. Journal of Paleontology 12:318-340.

GABRIELSE, $\mathrm{H}$

1967 Tectonic evolution of the northern Canadian Cordillera. Canadian Journal of Earth Sciences $4: 271-298$.

GABRIELSE. H., S.L. BUSSON, and J.A. RODDICK

1973 Geology of the Flat River, Glacier Lake, and Wrigley Lake Map-Areas, District of Mackenzie and Yukon Territory. Geological Survey of Canada, Memoir 366:1-153.

JONES, P.J.

1971 Lower Ordovician conodonts from the Bonaparte Gulf Basin and the Daly River Basin, northwestern Australia. Australia Bureau of Mineral Resources, Geology and Geophysics, Bulletin 117:1-80.

JONES, P.J., J.H. SHERGOLD, and E.C. DRUCE

1971 Late Cambrian and Early Ordovician stages in western Queensland. Journal of the Geological Society of Australia 18:1-32.

KURTZ, V.E.

1976 Biostratigraphy of the Cambrian and lowest Ordovician, Bighorn Mountains and associated uplifts in Wyoming and Montana. In Robison, R.A. and A.J. Rowell, eds., Paleontology and depositional environments: Cambrian of western North America. Brigham Young University, Geological Studies 23:215-227.

LANDING. E.

1977 "Prooneotodus" tenuis (Müller, 1959) apparatuses from the Taconic allochthon, eastern New York: construction, taphonomy, and the protoconodont "supertooth" model. Journal of Paleontology 51:1072-1084.

1978 Conodonts from the Gorge Formation (Late Cambrian-(now) Early Ordovician), northwestern Vermont. Geological Society of America, Abstracts with Programs 10:219. [Abstract].

1979 Studies in Late Cambrian-Early Ordovician conodont biostratigraphy and paleoecology. northern Appalachian region. Ph.D. Thesis, University of Michigan. 308 pp. 
LANDING. E. M.E. TAYLOR, and B.-D. ERDTMANN

1978 Correlation of the Cambrian-Ordovician boundary between the Acado-Baltic and North American faunal provinces. Geology 6:75-78.

LEE. H. Y

1975 Conodonts from the Upper Cambrian formations, Kangweon-Do, South Korea and its stratigraphical significance. Yonsei University, Graduate School Bulletin 12:71-89.

LINDSTRÖM. M.

1955 Conodonts from the lowermost Ordovician strata of south-central Sweden. Geologiska Föreningen i Stockholm, Förhandlingar 76:517-603.

LOCHMAN-BALK. C. and J.L. WILSON

1958 Cambrian biostratigraphy in North America. Journal of Paleontology 32:312-350.

LONGACRE. S.A.

1970 Trilobites of the Upper Cambrian Ptychaspid Biomere, Wilberns Formation, Central Texas. Paleontological Society Memoir 4:1-70.

LUDVIGSEN. R

1975 Ordovician formations and faunas, southern Mackenzie Mountains. Canadian Journal of Earth Sciences 12:663-697.

1979a Middle Ordovician trilobite biofacies, southern Mackenzie Mountains. In Stelck, C.R. and B.D.E. Chatterton, eds., Western and Arctic Canadian biostratigraphy. Geological Association of Canada, Special Paper 18:1-37.

1979b Trilobite biostratigraphy of the Cambrian-Ordovician boundary beds of the Rabbitkettle Formation, western District of Mackenzie. Canadian Biostratigraphy and Paleontology Seminar, Edmonton, September, 1979. [Abstract].

MILLER, J.F

1969 Conodont faunas of the Notch Peak Limestone (Cambro-Ordovician). House Range, Utah. Journal of Paleontology 43:413-439.

1970 Conodont evolution and biostratigraphy of the Upper Cambrian and lowest Ordovician. Ph.D. Thesis, University of Wisconsin. $137 \mathrm{pp}$.

1975 Conodont faunas from the Cambrian and lowest Ordovician of western North America. Geological Society of America. Abstracts with Programs 7:1200-1201. [Abstract]

1977 Conodont biostratigraphy and intercontinental correlations across the Cambrian-Ordovician boundary. 25th International Geological Congr 'ss, Sydney, 1977. Proceedings 1:274.

1978 Upper Cambrian and lowest Ordovician conodont faunas of the House Range, Utah. In Miller, J.F., ed., Upper Cambrian to Middle Ordovician conodont faunas of western Utah. Southwest Missouri State University, Geosciences Series 5:1-33.

MILLER. J.F. and H.J. MELB

1971 Trempealeauan conodonts. In Clark, D.L. ed. Conodonts and biostratigraphy of the Wisconsin Paleozoic. Wisconsin Geological and Natural History Survey, Information Circular $19: 4-9,78-81$

MILLER. R.H and E.A. PADEN

1976 Upper Cambrian stratigraphy and conodonts from eastern California. Journal of Paleontology 50:590-597.

MÜLLFR, K.J

1959 Kambrische Conodonten. Zeitschrift der Deutschen Geologischen Gesellschaft $111: 431-485$.

1971 Cambrian conodont faunas. In Sweet. W.C. and S.M. Bergström, eds., Symposium on conodont biostratigraphy. Geological Society of America, Memoir 127:5-20.

1973 Late Cambrian and Early Ordovician conodonts from northern Iran. Geological Survey of Iran, Report 3:1-76. 
MÜLLER, K.J. and D. ANDRES

1976 Eine Conodontengruppe von Prooneotodus tenuis (Müller, 1959) in natürlichem Zusammenhang aus dem oberen Kambrium von Schweden. Paläontologische Zeitschrift 50:193-200.

MÜLLER, K.J. and Y. NOGAMI

1971 Über den Feinbau der Conodonten. Kyoto University, Memoirs of the Faculty of Science, Series of Geology and Mineralogy 38:1-87.

MÜLLER. K.J., Y. NOGAMI, and H. LENZ

1974 Phosphatische Ringe als Mikrofossilien im Altpaläozoikum. Palaeontographica (Abt. A) 146:79-99

NOGAMI, Y.

1966 Kambrische Conodonten von China, Teil 1. Kyoto University, College of Sciences Memoir $33: 211-218$

NORFORD, B.S. and R.W. MACQUEEN

1975 Lower Paleozoic Franklin Mountain and Mount Kindle Formations, District of Mackenzie: their type sections and regional development. Geological Survey of Canada, Paper 74-34: $1-37$

NOWLAN, G.S.

1976 Late Cambrian to Late Ordovician conodont evolution and biostratigraphy of the Franklinian Miogeosyncline, eastern Canadian Arctic lslands. Ph.D. Thesis, University of Waterloo. $591 \mathrm{pp}$.

ÖZGÜL, N. and I. GEDIK

1973 Caltepe Limestone of Lower Paleozoic age from the middle Taurus Mountains and new information about the stratigraphy and conodonts of the Seydesehir Formation. Turkish Geological Association Bulletin 16:39-52. [In Turkish].

PANDER, C.H.

1856 Monographie der fossilen Fische des silurischen Systems der russisch-baltischen Gouvernements. St. Petersburg, Buchdruckerei der Kaiserlichen Akademie der Wissenschaften. $91 \mathrm{pp}$.

REINHARDT, J.

1974 Stratigraphy, sedimentology and Cambro-Ordovician paleogeography of the Frederick Valley, Maryland. Maryland Geological Survey, Report of Investigation 23:1-73.

REPETSKI. J.E.

1975 Conodonts from the El Paso Group (Lower Ordovician) of west Texas. Ph.D. Thesis. University of Missouri. $239 \mathrm{pp}$.

ROEHL. P.O

1967 Stony Mountain (Ordovician) and Interlake (Silurian) facies analogs of recent low-energy marine and subaerial carbonates, Bahamas. American Association of Petroleum Geologists Bulletin 51:1971-2031.

ROSS, R.J.. Jr.

1975 Early Paleozoic trilobites, sedimentary facies, lithospheric plates, and ocean currents. In Martinsson, A., ed., Evolution and morphology of the Trilobita, Trilobitoidea and Merostomata. Fossils and Strata 4:307-329.

1968 Practical significance of birdseye structures in carbonate rocks. Journal of Sedimentary Petrology 38:215-223. 
1971 Cambrian-Ordovician trilobites, western Arbuckle Mountains. Oklahoma Geological Survey Bulletin 110:1-83.

1977 Late Cambrian and earliest Ordovician trilobites, Wichita Mountains area, Oklahoma. Oklahoma Geological Survey Bulletin 124:1-79.

SWEET. W.C. and S.M. BERGSTRÖM

1972 Multielement taxonomy and Ordovician conodonts. Geologica et Palaeontologica, Sonderband 1:29-42.

TAYLOR. M.E

1977 Late Cambrian of western North America: trilobite biofacies, environmental significance, and biostratigraphic implications. In Kauffman, E.G. and J.E. Hazel, eds., Concepts and methods of biostratigraphy. Stroudsburg, Dowden, Hutchinson and Ross, pp. 397-425.

TIPNIS, R.S., B.D.E. CHATTERTON, and R. LUDVIGSEN

1979 Ordovician conodont biostratigraphy of the southern District of Mackenzie, Canada. In Stelck, C.R. and B.D.E. Chatterton, eds., Western and Arctic Canadian biostratigraphy. Geological Association of Canada, Special Paper 18:39-91.

VIIRA, V.

1974 Ordovician conodonts of the Baltic. Tallin, Institute of Geology of the Estonian SSR Scientific Academy. 142 pp. [In Russian].

WAMEL. W.A. van

1974 Conodont biostratigraphy of the Upper Cambrian and Lower Ordovician of north-western Öland, south-eastern Sweden. Utrecht Micropaleontology Bulletin 10:1-126.

WEBERS. G.F

1966 The Middle and Upper Ordovician conodont faunas of Minnesota. Minnesota Geological Survey Special Publication 4:1-123.

WILSON, J.L.

1969 Microfacies and sedimentary structures in "deeper water" lime mudstone. In Friedman, G.M., ed., Depositional environments in carbonate rocks. Society of Economic Paleontologists and Mineralogists Special Publication 14:4-19.

1970 Depositional facies across carbonate shelf margins. Transactions of the Gulf Coast Association Geological Society 20:229-233.

1974 Characteristics of carbonate platform margins. American Association of Petroleum Geologists Bulletin 58:810-824.

WINDER, C.G.

1976 Enigmatic objects in North American Ordovician carbonates. In Bassett, M.G., ed., The Ordovician System: Proceedings of a Palaeontological Association Symposium, Birmingham. Cardiff, University of Wales Press and National Museum of Wales, pp. $645-657$.

WINSTON, D. and H. NICHOLLS

1967 Late Cambrian and Early Ordovician faunas from the Wilberns Formation of Central Texas. Journal of Paleontology 41:66-96. 





ISBN 0-88854-265-8 ISSN 0384-8159 